\title{
Characteristics of Beaver Ponds and Landforms Induced by Beaver Activity, S Part of the Tuchola Pinewoods, Poland
}

\author{
Mirosław Rurek (D)
}

check for

updates

Citation: Rurek, M. Characteristics of Beaver Ponds and Landforms Induced by Beaver Activity, S Part of the Tuchola Pinewoods, Poland. Water 2021, 13, 3641. https:// doi.org/10.3390/w13243641

Academic Editor: Michele Mistri

Received: 11 November 2021 Accepted: 15 December 2021 Published: 18 December 2021

Publisher's Note: MDPI stays neutral with regard to jurisdictional claims in published maps and institutional affiliations.

Copyright: (C) 2021 by the author. Licensee MDPI, Basel, Switzerland. This article is an open access article distributed under the terms and conditions of the Creative Commons Attribution (CC BY) license (https:/ / creativecommons.org/licenses/by/ $4.0 /)$.
Department of Landscape History Research, Institute of Geography, Kazimierz Wielki University, Kościeleckich Square 8, 85-033 Bydgoszcz, Poland; mirur@ukw.edu.pl; Tel.: +48-52-349-6250

\begin{abstract}
Currently, there are only two species of beavers described-the North American beaver (Castor canadensis) and Eurasian beaver (Castor fiber). Their natural habitats are confined to the northern hemisphere but instances of beaver introduction to regions of the world they do not normally inhabit have also been recorded. The activity of beavers leads to changes in the natural environment linked to hydrological and geomorphological and plant cover transformations. Beavers live in natural and artificial water reservoirs and rivers. If the water level in the river is too low, they build dams to create a comfortable living environment. This paper aims to present changes in the relief of the valley inhabited by beavers in which sediments accumulate. During the field study, detailed measurements of dams and of the spatial range of beaver ponds were made, and the thickness and spatial distribution of accumulated sediments were determined. In addition, measurements of geomorphological forms in beaver ponds were also made. The samples of sediments were subject to grain-size distribution analysis, the results of which allowed calculating sediment parameters. Beavers appeared in the Gajdówka valley in the southern part of the Tuchola Forest (Poland) in 2008. In 2008-2011 they built 17 beaver dams that impounded ponds. The beaver ponds and beaver dams were of different sizes. They either flooded the whole flat bottom of the valley or only raised the level of water in the riverbed. A characteristic feature of beaver ponds is that they capture sediments. Different landforms were created in the course of the formation and disappearance of beaver ponds. It was established that these include alluvial fans, levees, sand shadow dunes and microterraces formed by deposition and erosion. They do not occur in all ponds. Points at which mineral sediments are supplied to the watercourse, including beaver burrows and erosion hollows, are presented together with the points at which sediments are transferred from ponds upstream to ponds downstream the watercourse. Beaver activity during valley colonization shows changes in the landscape caused by their presence and in particular their impact on the relief and deposition of sediments. Analysis of contemporary changes in the morphology of the Gajdówka Valley leads to the conclusion that beaver activity has had an intense impact on the terrain relief of the valley inhabited by beavers.
\end{abstract}

Keywords: beaver ponds; landforms; small valley; Tuchola Pinewoods

\section{Introduction}

The natural range of the beaver population is limited to the northern hemisphere. The North American beaver (Castor canadensis) lives in Canada and the United States, and the Eurasian beaver (Castor fiber) inhabits Europe and Asia [1-4]. The latest scientific studies concerning the population size and distribution of both species in Eurasia were presented in $[5,6]$. These authors analyzed the state of the beaver population in Eurasia, which ranges from 1,220,000 to 1,500,000 individuals. Landscape transformations induced by the activity of North American beavers consist of the results of the transformation of different components of the environment. Components such as water, geological structure, vegetation and relief [7-11] are subject to transformation. The introduction of the North American beaver to Argentina led to significant alterations in the landscape of the southern 
part of the country [12]. Castor canadensis and Castor fiber have a similar impact on landscape despite the former being slightly bigger [13].

Scientific research has covered the hydrological effects of the activity of beavers. In river valleys, beaver ponds contribute to altering river flow and increasing the local water level. The created ponds can be transformed into wetlands and meadows [14,15]. Beaver ponds-when filled with water-raise the level of groundwater, increasing water storage in the area inhabited by beavers [16]. They also contribute to the formation of backwaters that may lead to flooding larger than that observed in valleys not inhabited by beavers [17]

The geomorphological effects of beaver activity are related to their impact on the relief of the valley they inhabit. This is manifested in building dams, digging burrows and supplying wood to the watercourse $[18,19]$. Changes in the river channel during the existence of active beaver ponds imply its possible avulsion within the valley inhabited by beavers. This also refers to sediments deposited during water outflow. Examples of the above-described phenomenon were presented by Belgian and German researchers [20,21]. The existence of beaver ponds alters sediments. They capture and accumulate sediments, which overlay the bottom of the valley. The accumulated sediments are recognized in vertical arrangements of alluvia in U.S. river valleys [7,18,22-27].

Changes in landscape lead to raising the water table level, which affects plants within the pond's shoreline [28-30]. Changes in vegetation within beaver ponds are also induced by the presence of beavers [31]. Beavers feed on herbs and use wood for building dams and lodges. A single family can consist of four to six animals. Beavers live about 30 years and grow about $105 \mathrm{~cm}$ long including the tail. Their average weight is $30-35 \mathrm{~kg}$. They cause environmental transformations within a range of about $20 \mathrm{~m}$ from the watercourse [13].

Studies [32,33] present the results of field observations focusing on the activity of beavers associated with the vertical growth of sediments in valleys. Some U.S. [22,34,35] and English authors [36] demonstrate that beavers existed and were active in the Holocene. In Finland [37], remnants of a beaver dam dating back to 120,000 BP were found under glacial till.

Beaver activity studies in Poland covered the effects of their activity found in valleys they inhabit at present. Authors of the above-mentioned studies took into consideration hydrological changes in rivers inhabited by beavers [38-41], geomorphological effects in the area of the Polish Plain [42-44] and mountainous regions [45-47] and the impact on changes in the plant cover and water storage in river catchments [48,49]. Anthropogenic uses of rivers are associated with the construction of watermills now found as remnants such as pieces of buildings and gates. The study analyzing beaver activity on the rivers Mała Panew and Liswarta shows how beavers use former levees to create ponds [50]. Attempts at reconstructing the Holocene landscape transformed by beaver activity in Poland were presented based on the analysis of sediment structure in valleys and C14 dating [51-53]. However, the largest amount of information derives from the Middle Ages, which is supported by carbon dating of beaver cuts [54].

This paper aims to present the transformations of relief in beaver ponds in different water flow conditions as one of the factors determining the emergence of landforms caused by both sedimentation and erosion. Beavers settled in the Gajdówka River Valley and contributed to changes within the flat bottom of the valley. The forms are small, so it is important they are documented.

\section{Materials and Methods}

\subsection{Study Area}

The analyzed valley is located in the southern part of the Tuchola Forest (Figure 1), which is a forest ecosystem. Gajdówka is a first-order stream. Its length $(1.4 \mathrm{~km})$ and bed parameters (width $1.5 \mathrm{~m}$, depth $0.1-0.3 \mathrm{~m}$ ) provide a comfortable long-term living environment for beavers. In geomorphic terms, its valley is associated with the outwash plain of the Wda River formed by fluvioglacial waters at the stage of stagnation and recession of the Weichselian ice sheet from the moraines of the Pomeranian stage. It 
was cut in sand and gravel sediments of the Wda River outwash plain by rainwater and outflows from headwater areas. This part of the Wda River outwash plain is built from coarse-grained sand with a layer thickness not exceeding ten to twenty meters [55]. The absolute altitudes of the outwash plain range from 105 to $115 \mathrm{~m}$ above sea level (a.s.l.). The headwaters of the Gajdówka valley are located at about $105 \mathrm{~m}$ a.s.l., and its outlet at $90 \mathrm{~m}$ a.s.l. Currently, its waters supply Lake Wierzchy [56]. Mineral sediments not exceeding $3 \mathrm{~m}$ in thickness are deposited in the flat bottom of the valley, and the surface of the flat bottom is covered with mineral and organic sediments from beaver ponds. The valley has steep slopes (inclined up to $35^{\circ}$ ) overgrown with pine forests with occasional deciduous trees [56].

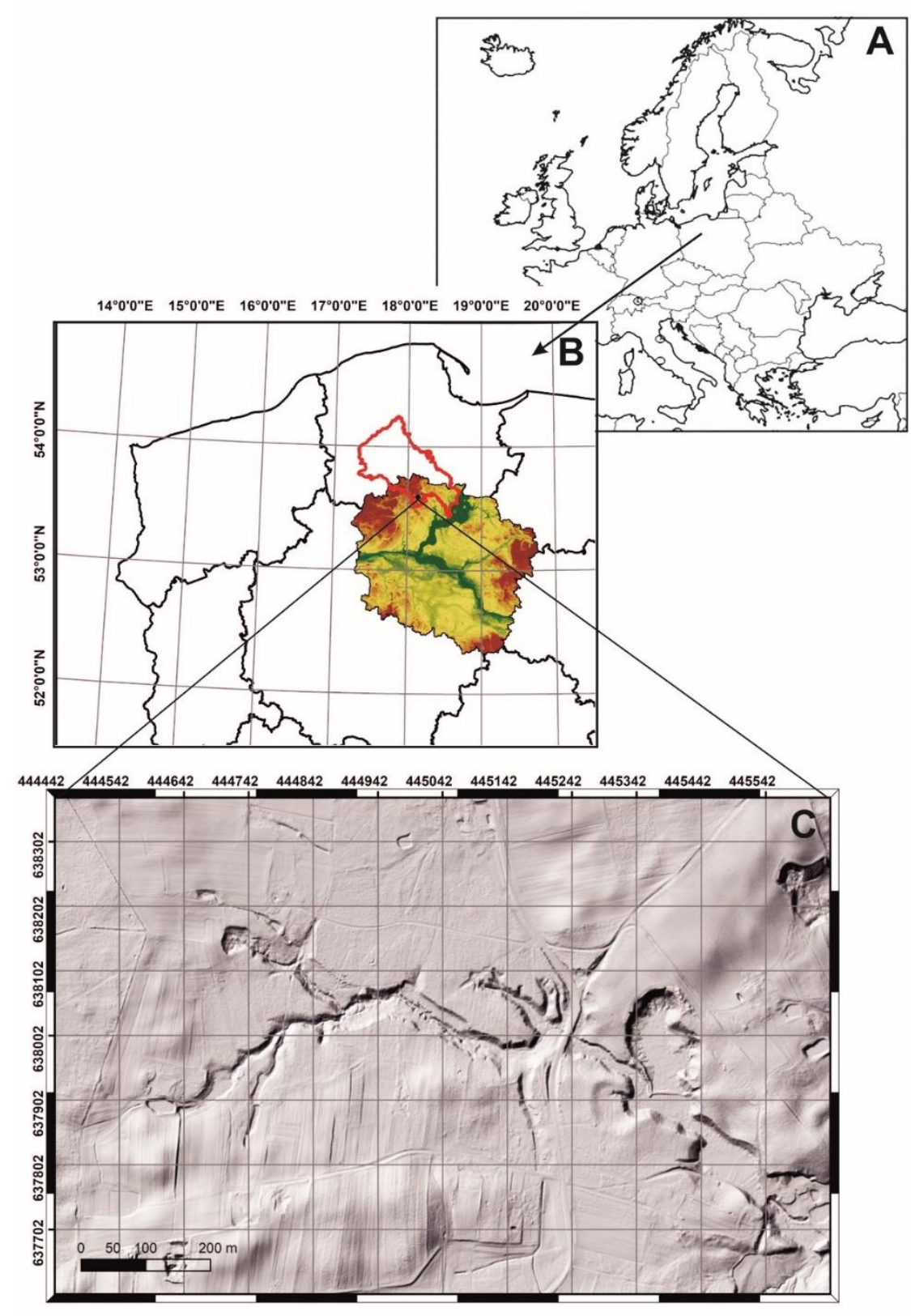

Figure 1. Location of the study area in Europe (A), Tuchola Forest (red line) in Kujawsko-Pomorskie voivodeship (hypsometrical map), Poland (B), and on digital elevation model LIDAR (C). Source: [57].

\subsection{Methods—Field and Desk Study}

Field observation was carried out in 2008-2011. During the field study, the beaver ponds on the Gajdówka stream were counted (Figure 2). In the study area, beavers created 
17 ponds at different points in time (Table 1 ). The analysis covered both active ponds and those that were abandoned and waterless.

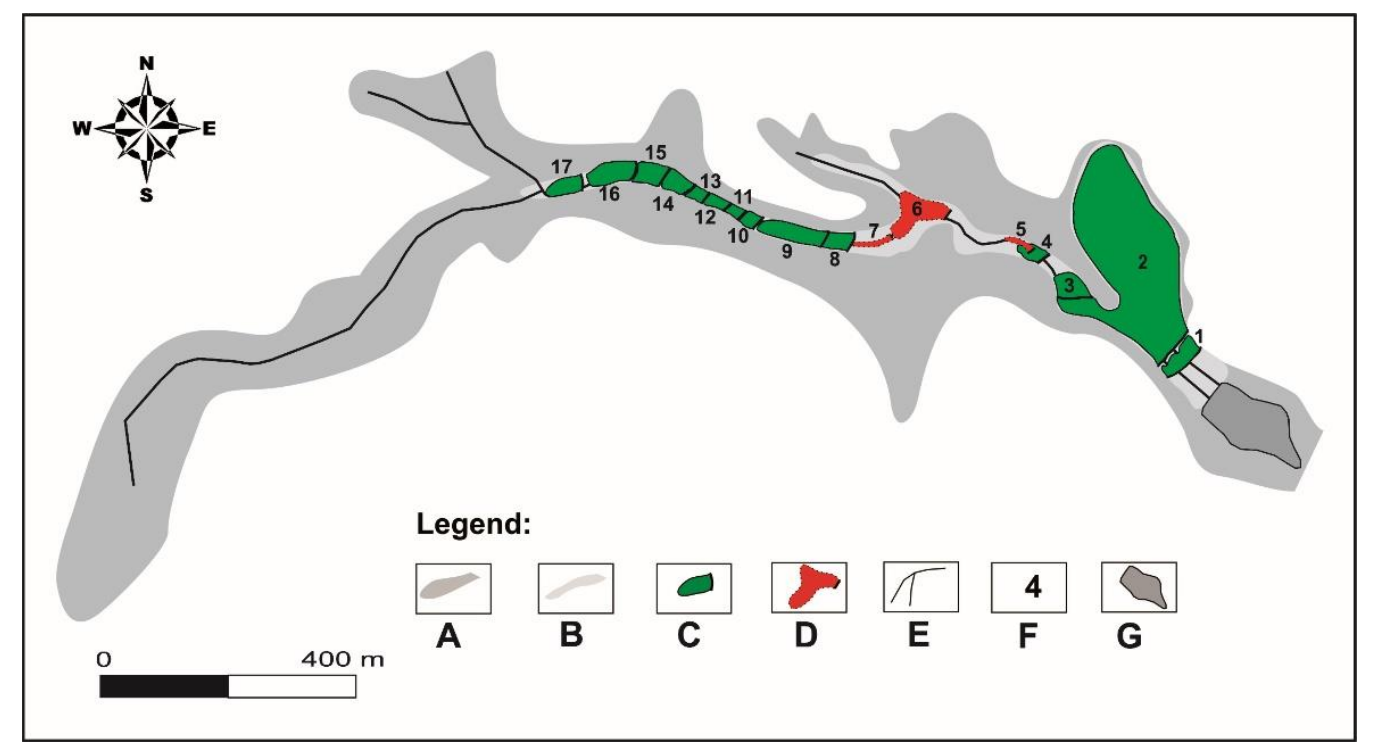

Figure 2. Sketch of the surface distribution of the analyzed beaver ponds with the division into active and inactive in the Gajdówka valley in 2011. (A) — range of the valley, (B) - flat bottom, (C)—active ponds, (D)—inactive ponds, (E) — river channel, (F)—pond numbers, (G) -mill pond. 1-17 are the number of ponds. Source: [56].

During the field study, the geometric parameters of beaver ponds, namely their length and width as well as the height of beaver dams, were measured. The length and width of beaver ponds were measured along with the height of beaver dams using a leveling rod and a measuring tape. The surface area of beaver ponds was calculated (Table 1). It was established by measurements perpendicular to the watercourse channel with reference to the water table level delineating the range of the pond. At least three width measurements were performed in each pond. Pond measurements were made before the dam, in the middle and in the initial section. Bigger ponds involved more width measurements. The length of the pond was measured from the dam to the beginning of the alluvial fan.

In addition, the range of sediment deposition was determined and the volume of sediments deposited in beaver ponds was computed (Table 1). The spatial distribution and thickness of sediments in beaver ponds were measured in both active and abandoned ponds. Spatial distribution measurements involved determining the reach of mineral and mineral-organic sediments in the ponds. It was not difficult as sediments are visible in a pond and can be identified according to colors (sand being a brighter color and mineral-organic silt being black), and in abandoned ponds they remain on the surface of the flooded bottom. The thickness of the sediment layer was measured using a PVC pipe with a diameter of $0.05 \mathrm{~m}$. The sediments were saturated with water, which facilitated measurement. The measuring tube was pushed into a layer of sediments until a point of resistance could be felt that was the original bottom of the valley prior to flooding. Due to differences in the surface of such measurements, their number ranged from several up to twenty-depending on the surface area of the pond. Sediment thickness is presented in Table 1 . The volume of sediments was computed based on the mean thickness of sediments in the pond and pond surface area. 
Table 1. Morphometric features of beaver ponds and accumulated sediments in the Gajdówka valley.

\begin{tabular}{|c|c|c|c|c|c|c|c|c|c|c|}
\hline \multirow{2}{*}{$\begin{array}{l}\text { Number } \\
\text { of Pond }\end{array}$} & \multirow{2}{*}{$\begin{array}{l}\text { Type of } \\
\text { Beaver } \\
\text { Pond }\end{array}$} & \multirow{2}{*}{$\begin{array}{c}\text { Length- } \\
\text { Height- } \\
\text { Width of the } \\
\text { Dam (m) }\end{array}$} & \multicolumn{3}{|c|}{$\begin{array}{l}\text { Morphometric Parameters of Beaver } \\
\text { Ponds }\end{array}$} & \multirow{2}{*}{$\begin{array}{c}\text { Average } \\
\text { Sediment } \\
\text { Thickness } \\
\text { (m) }\end{array}$} & \multirow{2}{*}{$\begin{array}{l}\text { Rate in } \\
\mathrm{cm} / \text { Year }\end{array}$} & \multirow{2}{*}{$\begin{array}{c}\text { Average } \\
\text { Sediment } \\
\text { Volume } \\
\left(\mathrm{m}^{3}\right)\end{array}$} & \multirow{2}{*}{$\begin{array}{l}\text { Duration } \\
\text { of Pond } \\
\text { Existence } \\
\text { in Years or } \\
\text { Months }\end{array}$} & \multirow{2}{*}{$\begin{array}{c}\text { Dominant } \\
\text { Type of } \\
\text { Sediment }\end{array}$} \\
\hline & & & $\begin{array}{l}\text { Maximum } \\
\text { Length (m) }\end{array}$ & $\begin{array}{c}\text { Average } \\
\text { Width (m) }\end{array}$ & Area $\left(\mathrm{m}^{2}\right)$ & & & & & \\
\hline 1 & floodplain & $26.5-0.6-1$ & 26 & 25.5 & 600 & 0.01 & 12 & 6 & 1 year & MOS \\
\hline 2 & floodplain & $26.5-0.8-1.3$ & 200 & 47.5 & 11,000 & 0.09 & 54 & 99 & 6 years & MOS/S \\
\hline 3 & floodplain & $26.5-1-1.5$ & 32 & 21 & 570 & 0.07 & 35 & 40 & 5 years & S/MOS \\
\hline 4 & floodplain & $15-0.6-1$ & 26 & 15 & 300 & 0.03 & 9 & 9 & 6 months & MOS/S \\
\hline 5 & channel & $3-0.3-0.5$ & 11 & 2.5 & 25 & 0.03 & 36 & 0.75 & 1 year & $\mathrm{S}$ \\
\hline 6 & floodplain & $2-1-1.5$ & 35 & 6 & 300 & 0.05 & 11 & 15 & 3 months & S/MOS \\
\hline 7 & channel & $0.8-0.8-1.3$ & 13 & 0.7 & 13 & 0.28 & 63 & 3.6 & 3 months & $\mathrm{S}$ \\
\hline 8 & floodplain & $4-0.5-1$ & 15 & 4.8 & 57 & 0.14 & 28 & 9 & 2 years & $\mathrm{S}$ \\
\hline 9 & floodplain & $15-0.5-1$ & 35 & 13 & 430 & 0.09 & 27 & 38.7 & 3 years & MOS/S \\
\hline 10 & floodplain & $4-1-1.5$ & 5 & 5 & 25 & 0.01 & 12 & 0.25 & 1 month & $\mathrm{S}$ \\
\hline 11 & floodplain & $4-1-1.3$ & 5 & 4.5 & 23 & 0.01 & 12 & 0.23 & 1 month & $\mathrm{S}$ \\
\hline 12 & floodplain & $4-1-1.2$ & 5 & 4.5 & 23 & 0.03 & 2 & 0.7 & 1 month & $\mathrm{S}$ \\
\hline 13 & floodplain & $4.5-1-1.4$ & 5 & 5 & 25 & 0.03 & 2 & 0.75 & 1 month & $\mathrm{S}$ \\
\hline 14 & floodplain & $5-1-1.5$ & 18 & 4.8 & 100 & 0.28 & 84 & 2.8 & 3 years & $\mathrm{S}$ \\
\hline 15 & floodplain & $5-0.8-1.3$ & 15.5 & 5.1 & 90 & 0.05 & 15 & 4.5 & 3 years & $\mathrm{S}$ \\
\hline 16 & floodplain & $8-1.2-1.6$ & 35 & 8.7 & 250 & 0.07 & 21 & 17.6 & 3 years & S/MOS \\
\hline 17 & floodplain & $\begin{array}{c}7-0.8-1.3 \\
\text { Total }\end{array}$ & 36 & 6.3 & $\begin{array}{c}252 \\
14,083\end{array}$ & 0.02 & 4 & $\begin{array}{c}5 \\
25288\end{array}$ & 2 years & MOS/S \\
\hline
\end{tabular}

${ }^{1}$-MOS, mineral-organic silt; $\mathrm{S}$, sands.

In addition, beaver dams-as finely reinforced water damming structures-were measured. This allowed measuring their parameters directly with a measuring tape. The length of beaver dams was measured along the dam's crest, according to its linear arrangement in the valley. Each dam was measured one time. The width of beaver dams was measured at their feet. Stagnant water in beaver ponds made the measurements difficult, so at the beginning, using a leveling rod, the reach of the foot was established by knocking the rod against the dam until the bottom of the valley was captured and then the measurement followed. It was difficult to establish the width of beaver dams since they were sealed with silt and grass on the beaver pond side. Therefore, in some cases, the widths of beaver dams were estimated widths only. The height of beaver dams was measured with a leveling rod. It was measured on the distal side where the water level is lower. In ponds in which the water level later dropped, the results of previous measurements were rechecked.

During the field study, landforms created inside and outside beaver ponds were explored. Some of them were recognized only after the water level had dropped or the ponds had been completely dried out. It was observed that they were mainly alluvial fans, levees, channel bars and channel microterraces. They were measured with a measuring tape. Length, width and height were measured. The geological structures were explored in open pits made in sediments building the forms and through manual drilling.

Grain size was analyzed in an AS 200 Basic sieve shaker with a set of sieves made by Retsch GMBH, Haan, Germany. The mesh was selected according to the [58] scale (1922) as $2,1,0.5,0.25,0.125$ and $0.063 \mathrm{~mm}$. The results showed the percentage share of the fraction represented on a grain-size curve. Data obtained from the grain-size distribution analysis were used for computing sedimentological indicators. They were computed using the Folk and Ward method [59] and included mean grain size $(\mathrm{Mz})$ and sorting $(\sigma \mathrm{I})$. The calculations were made with Gradistat 5.11 Pl Beta (Kenneth Pye Associates Ltd., Wokingham, UK) software based on the functions of Microsoft Excel.

\section{Results}

\subsection{Ponds and Pond Types}

In the analyzed area, beavers made 17 beaver ponds in 2008-2011 (Figure 1). As reported by the employees of the Trzebciny Forest Inspectorate, pond 2 (Table 1) existed from 2005 and was the oldest of all the recorded ponds. Other ponds were formed by damming the flat bottom of the valley in whole or in part or by damming of the stream channel only. In 2008 seven beaver ponds were found, of which only two survived until 2011 (Table 1, ponds 2 and 3). The highest number of beaver ponds was recorded in 2009. Eight of them were found. The results of field studies pertaining to the analyzed period 
show that beaver ponds may be abandoned by beavers but remain water storage reservoirs for a long time. Due to the degradation of beaver dams by human activity or water pressure, some ponds existed for only a month or several months (Table 1). The surface area of the pond depends on the length and height of the beaver dam and its situation in the relief of the valley. In the study area, beaver ponds were formed in the stream channel and on the floodplains. In the study period, only two beaver ponds were discovered in the stream channel. Other ponds were floodplain ponds, the water of which flooded the bottom of the valley (Figure 2). The reach of the water in a beaver pond determined its shape. It should be noted that the reach of the pond is connected with the relief of the valley and with the beaver dam. Beaver dams found in the study area differed in size (Table 1). They were finely reinforced structures built from wood and available organic and mineral material. Observations of beaver dams lead to the conclusion that beavers did not use stones to build them. Studies linked to the exploration of the geological structure show that in the vicinity of the Gajdówka valley there are no sediments with grains coarser than gravel. When beavers abandoned their habitat, the dams were overgrown with vegetation but their shape and wooden material was discernible on the flat bottom of the valley. Wood used for their construction was not even-aged. Pieces of willow wood showing recent beaver teeth marks were found together with older pieces (dark-colored wood) probably dating back to the previous beaver colonization. The evidence is a beaver burrow dug in the left-side bank of the valley. The longest dams were found next to ponds 1, 2 and 3 . They were nearly straight-line and passed between trees that made them stable. The shortest dam was $0.8 \mathrm{~m}$ long and dammed water in channel pond number 7 . The other dams were several meters long with some ranging from ten to twenty meters long (Table 1). The study revealed cascaded beaver ponds in the upstream section of the valley. The dams were spaced at $5 \mathrm{~m}$ each, which is a peculiar and rarely seen pattern. Moreover, the number of ponds on such a short stream implies a strong interference of beavers in the natural environment. The density of ponds in this valley is 14 ponds per $1 \mathrm{~km}$.

\subsection{Types of Forms}

Four types of forms closely related to the presence of beavers were identified in beaver ponds. These include alluvial fans, levees, sand shadow dunes and microterraces. Field observation shows that they are not present in all beaver ponds (Table 2).

Table 2. Morphometric characteristics of forms and the location of forms in individual ponds in the Gajdówka valley.

\begin{tabular}{|c|c|c|c|c|c|c|c|c|}
\hline \multirow[b]{2}{*}{$\begin{array}{c}\text { Number of } \\
\text { Pond }\end{array}$} & \multirow[b]{2}{*}{$\begin{array}{c}\text { Type of } \\
\text { Beaver Pond }\end{array}$} & \multirow[b]{2}{*}{ Alluvial Fan ${ }^{1}$} & \multirow[b]{2}{*}{ Levees $^{1}$} & \multirow[b]{2}{*}{$\begin{array}{c}\text { Sandy Shadow } \\
\text { Dunes }^{1}\end{array}$} & \multirow[b]{2}{*}{ Microterraces $^{1}$} & \multicolumn{3}{|c|}{ Morphometry of Forms } \\
\hline & & & & & & Length (m) & Width (m) & $\begin{array}{l}\text { Height/ } \\
\text { Thickness of } \\
\text { Sediments } \\
(\mathrm{m})\end{array}$ \\
\hline 1 & floodplain & - & - & - & - & - & - & - \\
\hline 2 & floodplain & + & - & - & - & 3 & 2 & 0.03 \\
\hline 3 & floodplain & + & - & - & - & 5 & 3 & 0.05 \\
\hline 4 & floodnlain & + & - & - & & 3 & 2 & 0.03 \\
\hline 4 & floodplain & & & & + & 1 & $0.1-0.5$ & 0.05 \\
\hline 5 & channel & - & - & - & - & - & - & - \\
\hline 6 & floodplain & - & + & - & - & 10 & $0.2-0.7$ & 0.25 \\
\hline 7 & channel & - & - & - & - & - & - & - \\
\hline & & + & & - & & 3 & 2 & 0.03 \\
\hline 8 & floodplain & & + & & & 5 & $0.2-0.5$ & 0.15 \\
\hline & & & $T$ & & + & 8 & $0.1-0.3$ & $\begin{array}{c}0.15 \\
0.1\end{array}$ \\
\hline & & + & & - & & 5 & 3 & 0.05 \\
\hline 9 & floodplain & & + & & & 12 & $0.2-0.6$ & 0.2 \\
\hline & & & & & + & 20 & $0.1-0.6$ & 0.1 \\
\hline 10 & floodplain & - & - & - & - & - & - & - \\
\hline 11 & floodplain & - & - & - & - & - & - & - \\
\hline 12 & floodplain & - & - & + & - & 2 & $0.2-0.7$ & 0.2 \\
\hline 13 & floodplain & - & - & + & - & 3 & $0.2-0.7$ & 0.2 \\
\hline 14 & floodplain & + & - & - & - & 4 & 3 & 0.03 \\
\hline 15 & floodplain & + & - & - & & 3 & 2 & 0.03 \\
\hline 10 & & + & & _- & + & 2 & $0.1-0.3$ & 0.05 \\
\hline 16 & floodplain & + & + & - & & 5 & $2^{2}$ & 0.05 \\
\hline & Iloodplain & & & & + & $\begin{array}{l}10 \\
10\end{array}$ & $\begin{array}{l}0.2-0.3 \\
0.1-0.4\end{array}$ & $\begin{array}{l}0.15 \\
0.05\end{array}$ \\
\hline 17 & floodplain & + & - & - & - & 3 & 2 & 0.03 \\
\hline
\end{tabular}

${ }^{1}$-a plus mark (+) denotes ponds in which the specific form was present, and a minus (-) indicates ponds in which such forms were not found. 


\subsubsection{Alluvial Fans}

Alluvial fans accumulate in the beaver pond backwater zone and were found in nine ponds (Table 2). These are forms marking the line that separates flowing water from stagnant water. Their size does not change in active ponds. They have a fan-like arrangement (Figure 3). These forms feature different sizes. The length of fans does not exceed $5 \mathrm{~m}$-the longest fans were found in ponds 3,9 and 16 . In pond 14, the fan was $4 \mathrm{~m}$ long; in ponds $2,4,8,15$ and 17 , the fans were not longer than $3 \mathrm{~m}$. In most cases the width of such forms was similar. In ponds 3,9 and 14 , it was $3 \mathrm{~m}$; in other ponds-2, 4 , $8,15,16$ and 17-it was less than $2 \mathrm{~m}$. Most of these forms are evenly distributed in the pond. The thickest fans were found in ponds 3,9 and $16-0.05 \mathrm{~m}$. In ponds $2,4,8,14$, 15 and 17 , sediments making the fans were only $0.03 \mathrm{~m}$ thick. Due to the small thickness of sediments and vegetation rapidly encroaching the dried fans, traces of the original sedimentary structures are obliterated.
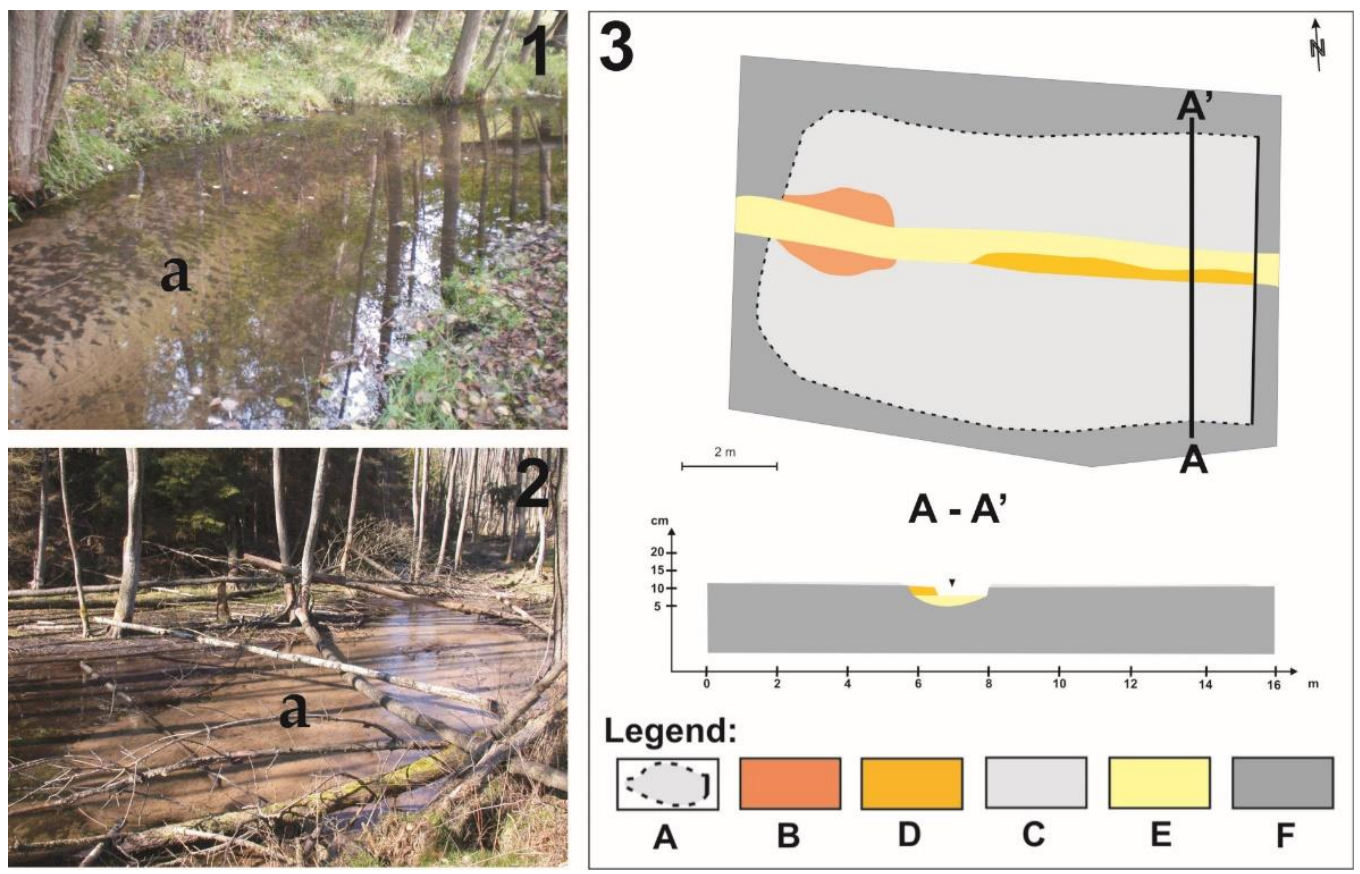

Figure 3. Example of alluvial fans and their distribution in beaver pond 3 and a sketch with the distribution of forms in a beaver pond and their geological structure. Legend: part (1) and (2) = aalluvial fans; part (3) = (A) —range of a beaver pond, (B) —alluvial fan sands, (C) — microterrace sands, (D) — mineral-organic silt, (E) — channel sands, (F) — bottom of the valley. (A-A') is the geological cross-section.

\subsubsection{Levees}

Levees are formed on both sides of the flooded stream channel (Figure 4). They were identified in ponds 6, 8, 9 and 16 (Table 2). The longest sandy levee of more than $12 \mathrm{~m}$ was formed in pond 9. In ponds 6 and 16, the levees were $10 \mathrm{~m}$ long. By contrast, in pond 8 the sandy levee was only $5 \mathrm{~m}$ long. Apart from length, the width of levees was also measured at their narrowest and widest points. In all the ponds the smallest width was $0.2 \mathrm{~m}$. The widest sandy levee- $0.7 \mathrm{~m}$-was found in pond 6, while in pond 9 it was less than $0.6 \mathrm{~m}$. By contrast, in ponds 8 and 16 it was $0.5 \mathrm{~m}$ wide. As regards the height of these forms, the tallest levee was found in pond 6 . It was $0.25 \mathrm{~m}$ tall. In pond 9 the levee was $0.2 \mathrm{~m}$ tall, and in ponds 8 and 16 , the levees were of equal height -0.15 meters. Massive structures were found in sandy levees. 

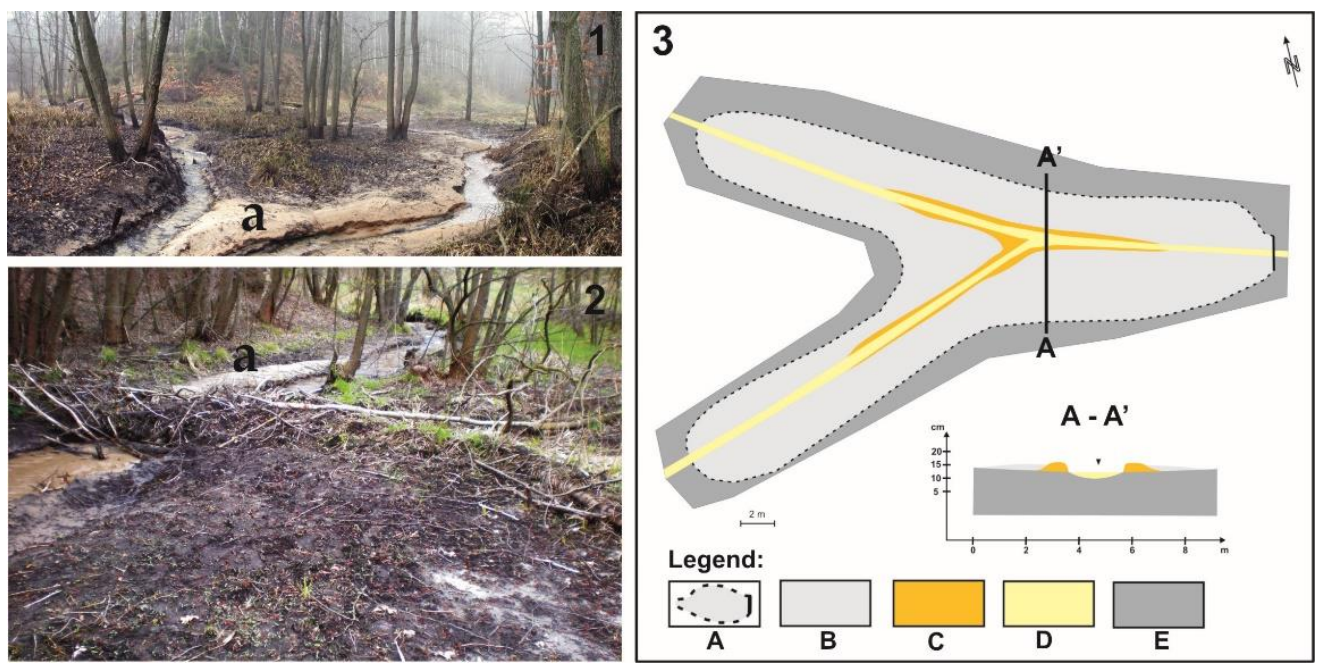

Figure 4. Example of levees and their distribution in beaver pond 6 and a sketch with the distribution of forms in a beaver pond and their geological structure. Legend: part (1) and (2) = a-levees; part (3) $=(\mathbf{A})$ —range of a beaver pond, (B) — mineral-organic silt, (C) —levee sands, (D) —channel sands, (E) - bottom of the valley. (A-A') is the geological cross-section.

\subsubsection{Sandy Shadow Dunes}

Sandy shadow dunes were found in beaver ponds 12 and 13 formed in a cascaded pattern (Figure 5). They are located downstream of the beaver dam on pond number 14 (pond number 13) and downstream of the beaver dam on pond number 13 (pond number 12). The examined forms are not longer than $3 \mathrm{~m}$. A sandy shadow dune of $3 \mathrm{~m}$ was found in pond 13. The sandy shadow dune in pond 12 was $2 \mathrm{~m}$ long. The width of these forms ranges from 0.2 to $0.7 \mathrm{~m}$ and is identical in both cases. Both forms have an identical height not exceeding 0.2 meters. Massive structures without clear stratification were identified in sandy shadow dunes.

\subsubsection{Microterraces}

Microterraces are created within the channel at the stage of disappearance of a beaver pond as a result of damaging the beaver dam. They were found in five beaver ponds (Table 2, Figure 6). The forms are of different lengths. The longest microterrace found in pond 9 was $20 \mathrm{~m}$ long. A microterrace in pond 8 was $10 \mathrm{~m}$ long; in pond $14,8 \mathrm{~m}$. The shortest microterraces were found in ponds $15(2 \mathrm{~m})$ and $4(2 \mathrm{~m})$. The width of these forms was measured at the narrowest and widest points. The narrowest point for all microterraces was $0.1 \mathrm{~m}$ wide. At the widest point, a microterrace found in pond 9 was $0.6 \mathrm{~m}$ wide. In other points, the width was $0.5 \mathrm{~m}$ in pond $4,0.4 \mathrm{~m}$ in pond 16 and $0.3 \mathrm{~m}$ in ponds 8 and 15 . Sediments determining microterrace height were $0.1 \mathrm{~m}$ thick in ponds 8 and 9 . By contrast, in ponds 4,15 and 16 they were only $0.05 \mathrm{~m}$ thick. Massive structures were identified in the microterraces. 

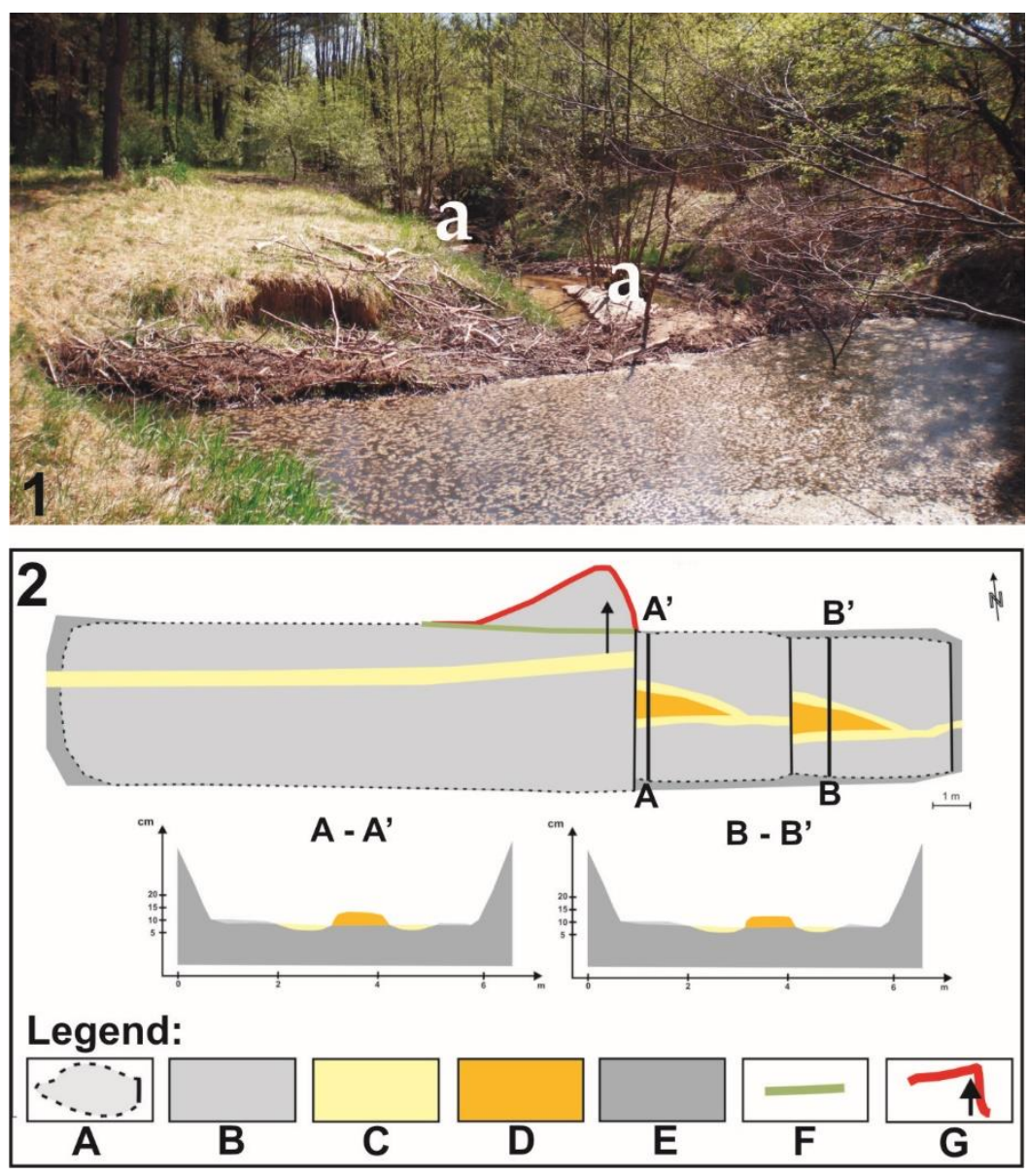

Figure 5. Example of sandy shadow dunes and their distribution in beaver ponds 12 and 13 and a sketch with the distribution of forms in a beaver pond and their geological structure. Legend: part (1) = a-sandy shadow dunes; part $(2)=(\mathbf{A})$-range of a beaver pond, (B) - mineral-organic silt, (C) — channel sands, (D) — sandy shadow dune sands, (E) — bottom of the valley, (F) — shore line before erosion, $(\mathbf{G})$ - shore line after erosion. $\left(\mathbf{A}-\mathbf{A}^{\prime}\right)$ and $\left(\mathbf{B}-\mathbf{B}^{\prime}\right)$ are the geological cross-sections.

\subsubsection{Genesis of Landforms from Beaver Ponds}

Accumulation fans are formed at the beginning of the beaver pond. Due to the small thickness of sediments and vegetation rapidly encroaching the dried fans, traces of the original sedimentary structures are obliterated. Most likely at the initial stage of alluvial fan growth, structures induced by current occur, but this is difficult to ascertain due to continuous flooding. Differences in fan size depend on the supplies of sandy material and the relief of the flooded valley. When the supplies of sandy sediments are continuous, the energy of the flowing water is variable and the pond exists sufficiently long, sandy sediments can reach as far as the dam. Then, the sand covers the previously deposited mineral and organic silt (Figure 7A). Such a phenomenon was observed in ponds 3, 5 and 8. Ponds were backfilled with sand due to sand being supplied from active beaver ponds located upstream, and most of all from the developing erosion hollows. Erosion hollows were formed at the dam-slope interface, which resulted in transferring sandy sediments into ponds located downstream. Water flowing in the relief channel prevented deposition in ponds in which the hollows existed. 

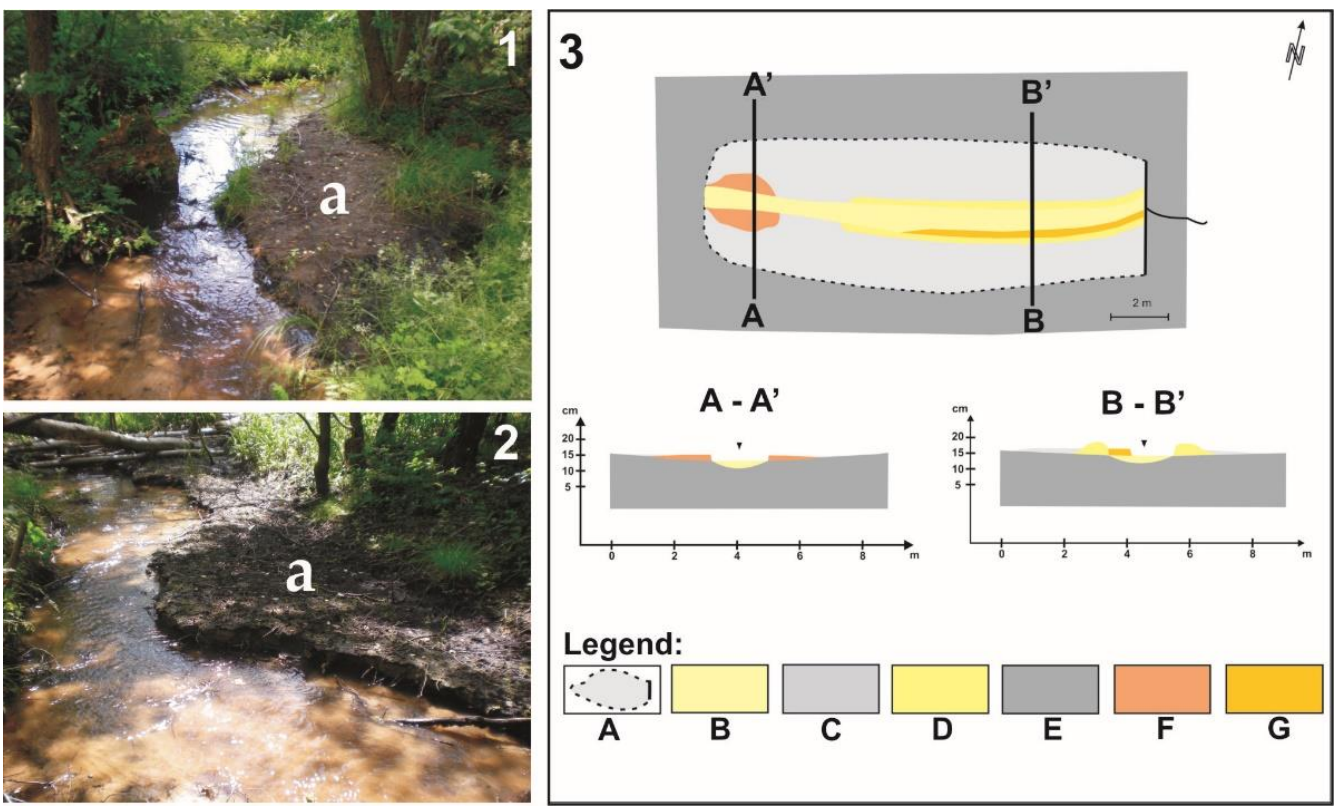

Figure 6. Example of microterraces and their distribution in beaver pond 9 and a sketch with the distribution of forms in a beaver pond and their geological structure. Legend: part (1) and (2) = a - microterraces; part (3) = (A) —range of a beaver pond, (B) —channel sands, $(\mathbf{C})$ - mineral-organic silt, (D) - levee sands, (E) — bottom of the valley, (F) —alluvial fan sands, (G) - microterrace sands. $\left(\mathbf{A}-\mathbf{A}^{\prime}\right)$ and $\left(\mathbf{B}-\mathbf{B}^{\prime}\right)$ are the geological cross-sections.

Levees develop when the bed of the channel is raised by a developing beaver pond. Sediments deposited in the channel raise the stream bed to a height resulting in water overflowing the stream channel, which contributes to the development of sandy levees at the stage of flooding. When the water level drops and the channel is lowered back to the level before the flooding, levee-like forms emerge. Levees were formed by deposition at the initial stage of floodplain pond development. Massive structures were found in sandy levees. In one case the sand was interbedded with mineral and organic silt laminas. This pattern was formed by a redevelopment of a beaver pond on the stream, which led to the levee being topped with new sediments (Figure 7B).

Sandy shadow dunes were formed in the shadow of alders growing in a narrow zone of the flat bottom of the analyzed stream. As shown by the sediment distribution surveys, in cascaded ponds sediments are distributed in evenly thick layers. However, the flood flow formed sandy shadow dunes from the transported sediments behind tree trunks in the central part of the pond. When the dam was broken, the channel did not resume the shape it had before the pond was formed, and instead, was split into two separate new channels. Sandy shadow dunes were created by the deposition of sandy sediments and were exposed only after the pond was completely dried out (Figure 7C).

The erosive landforms are microterraces. They were identified only in floodplain ponds formed by partial or whole flooding of the valley. Their origin is associated with the raising of the stream bed while the beaver pond is being filled with water. After the beaver pond is emptied, the water level in the channel returns to the level measured before the flooding and erosional microterraces (water level marks) are formed at the bank. The condition is that the runoff returns to the old channel (Figure 7D). They continue almost along the whole channel in the former pond. Sometimes these forms are hardly discernible as grass rapidly encroaches their surface. 

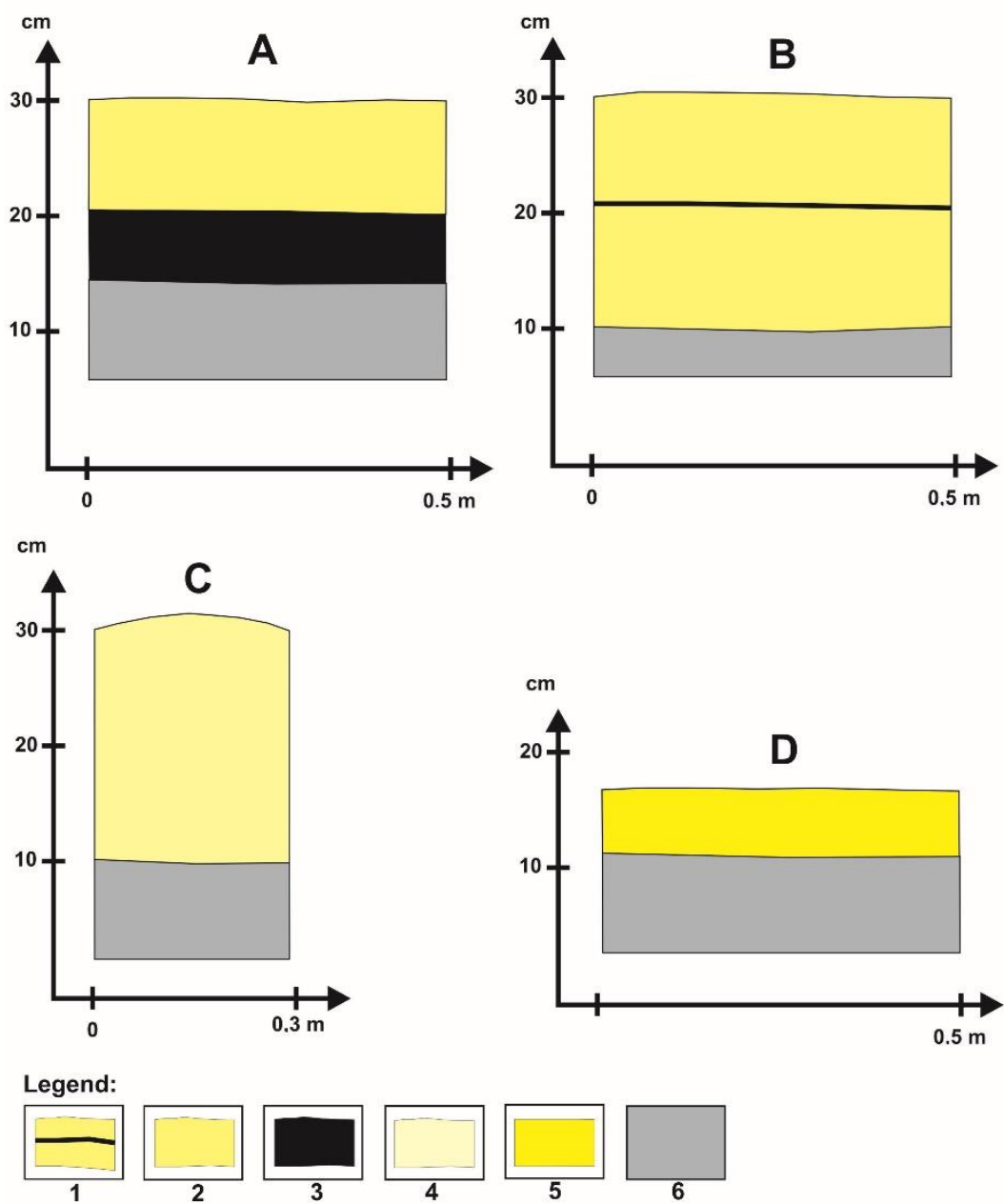

Figure 7. Examples of sedimentary structures in geomorphological forms formed in beaver ponds in Gajdówka valley. Geological structure in forms: (A)—alluvial fan, (B)—levee, (C)—sandy shadow dune sands, (D) — microterrace. (1) — levee sands with dark laminate mineral-organic silt, (2) alluvial fan sands, (3) - mineral-organic silt, (4) — sandy shadow dune sands, (5)—microterrace sands, (6) -alluvial sands.

\subsection{Types of Sediments}

Sediments are deposited in beaver ponds. Due to the fluvial flow and stagnant water in the pond, the sediments are represented by sand and mineral-organic silt. Observations show that these sediments are distributed throughout the beaver pond and make the thickest layers next to the dam. The thickness of sediments is affected by how long the pond exists and the supply of mineral and organic sediments. According to Table 1, the ponds existed in different time periods. The longest existing was pond 2 in which the sediments deposition rate was $54 \mathrm{~cm} /$ year. The shortest existing were ponds 10, 11, 12 and 13 . They were four out of seven cascaded ponds. The highest deposition rate- $84 \mathrm{~cm} /$ year-was calculated for pond 14. The lowest deposition rate was recorded in ponds 12 and 13 . That is $2 \mathrm{~cm} /$ year.

The volume of accumulated sediments varies depending on how long a beaver pond is active. The highest amount of sediments was accumulated in pond 2 . The pond was active for six years. In pond 3 the volume of sediments was $40 \mathrm{~m}^{3}$, and beavers lived in it for five years. In addition, $38.7 \mathrm{~m}^{3}$ of sediments were deposited in pond 9 which was active for three years. The smallest amount of sediments was found in ponds 10, 11, 12 and 13. The volume of sediments in each pond did not exceed $1 \mathrm{~m}^{3}$. The total volume of sediments is $252.88 \mathrm{~m}^{3}$ (Table 1 ). 


\subsubsection{Sand}

Mineral sediments are represented by medium, fine and very fine grained sands (Table 3). Their spatial distribution and thickness determine the size of ponds, the amount of material supplied to them and the length of time the reservoirs exist. In addition to mineral fraction, the sand contained a high share of organic particles. The thickness of sandy sediments depends on the supply or transfer of mineral sediments within ponds. During field studies it was determined that it did not exceed 35 centimeters in floodplain ponds (Figure 8). In channel ponds (pond 8) the maximum thickness of sandy sediments can be 80 centimeters.

Table 3. Grain size analysis results of sediments collected from forms occurring in beaver ponds in the Gajdówka valley.

\begin{tabular}{|c|c|c|c|c|c|c|c|c|}
\hline \multirow{2}{*}{ Sample Number } & \multirow{2}{*}{ Types of Sediments and Forms } & \multicolumn{7}{|c|}{ Percentage Part of the Fraction Range by the Wentworth Scale [59] (in mm) } \\
\hline & & $>2.00$ & $1.0-2.0$ & $0.5-1$ & $0.25-0.5$ & $0.125-0.25$ & $0.063-0.125$ & $<0.063$ \\
\hline \multirow[t]{2}{*}{1} & Sand, Alluvial fan, pond 3 & 0.65 & 0.93 & 4.16 & 32.52 & 46.17 & 12.12 & 3.44 \\
\hline & \% cumulative & 0.65 & 1.58 & 5.75 & 38.26 & 84.44 & 96.56 & 100.00 \\
\hline \multirow[t]{2}{*}{2} & Sand, Alluvial fan, pond 3 & 0.00 & 0.34 & 4.64 & 41.82 & 47.50 & 5.58 & 0.12 \\
\hline & $\%$ cumulative & 0.00 & 0.34 & 4.98 & 46.80 & 94.30 & 99.88 & 100.00 \\
\hline \multirow[t]{2}{*}{3} & Sand, Levees pond 8 & 0.00 & 0.26 & 5.88 & 38.74 & 48.67 & 6.34 & 0.12 \\
\hline & $\%$ cumulative & 0.00 & 0.26 & 6.14 & 44.88 & 93.55 & 99.88 & 100.00 \\
\hline \multirow[t]{2}{*}{4} & Sand, Levees pond 9 & 0.00 & 0.27 & 5.67 & 37.93 & 45.46 & 10.11 & 0.55 \\
\hline & $\%$ cumulative & 0.00 & 0.27 & 5.95 & 43.88 & 89.33 & 99.45 & 100.00 \\
\hline \multirow[t]{2}{*}{5} & Sand, Alluvial fan, pond 4 & 0.00 & 0.15 & 0.99 & 11.78 & 58.24 & 26.90 & 1.94 \\
\hline & $\%$ cumulative & 0.00 & 0.15 & 1.14 & 12.92 & 71.16 & 98.06 & 100.00 \\
\hline
\end{tabular}

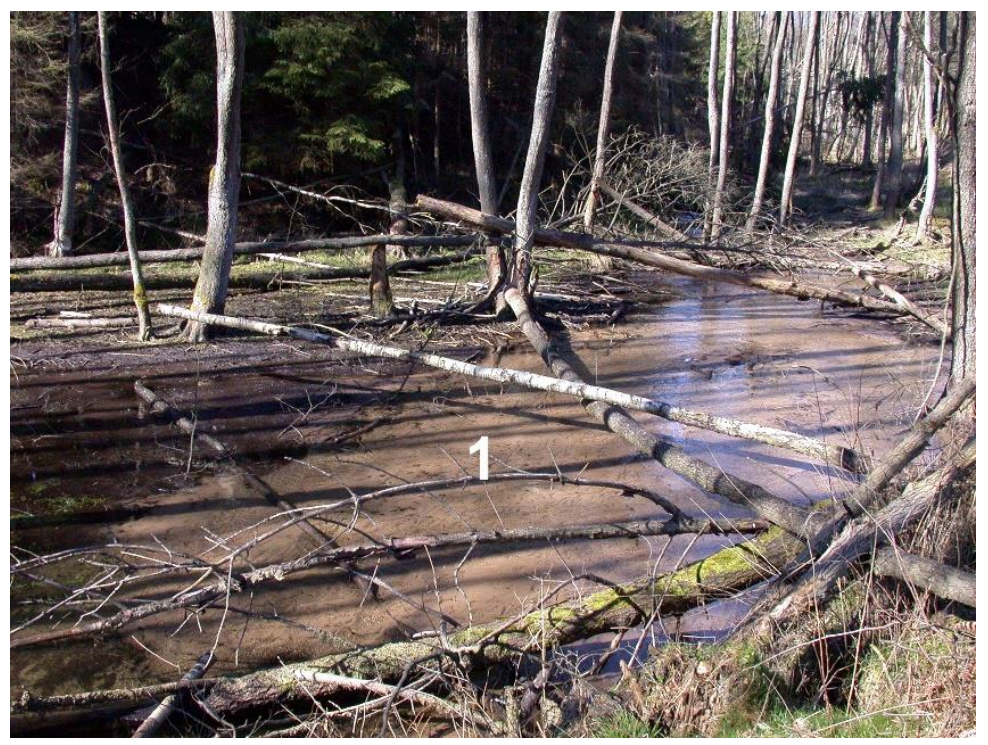

Figure 8. Mineral deposits (1-sands) of the accumulation fan in beaver pond 3 in Gajdówka valley.

\subsubsection{Mineral-Organic Silt}

Mineral-organic silt resembling alluvial soils is deposited in beaver ponds. Such sediments can be described in Holocene profiles as alluvial soils. In ponds 2, 3, 6 and 9, the thickness of mineral-organic sediments ranges from 5 to 15 centimeters. The thickest layers of sediments were identified next to the beaver dams on the pond side, and they become thinner towards the alluvial fan. They contain a dusty fraction and a high share of organic material. They are black. Mineral-organic silt overlays sands or occurs as interbeddings between sands. Silt in beaver ponds is associated with deposition in still or slowly running water, and its interbeddings can imply that beavers had abandoned their habitat and the alluvial fan had encroached the pond (Figure 9). 


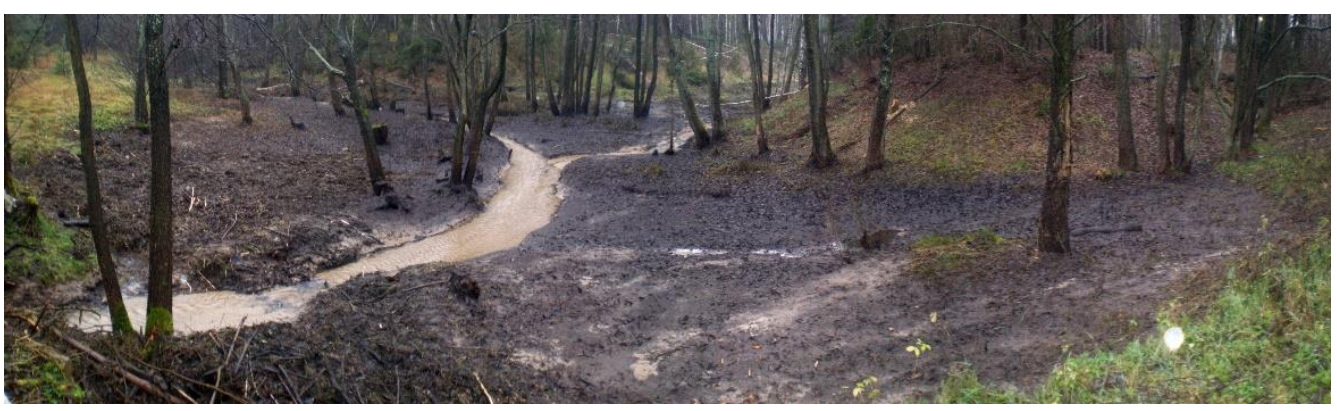

Figure 9. Sediments of the beaver pond (black color) after draining the water (pond 6) in Gajdówka valley.

\subsubsection{Sedimentary Characteristics}

The results of grain-size analysis show the highest share of fine-grained sand (Table 3), the maximum percentage of which was found in the alluvial fan in pond number 4 (58.24\%). The lowest percentage was found in sample 1 from the alluvial fan in pond $3(46.17 \%)$. A coarser-grained fraction was identified in one sample only and accounted for $0.65 \%$ of the whole sample (sample 1). A silt fraction was present in all the samples, and its highest content was measured also in sample $1(3.44 \%)$. It should be also noted that next to the predominant fine-grained fraction, the content of a medium-grained fraction is also high.

The grain-size distribution curves in the figure are of a similar shape (Figure 10). This indicates moderate sorting. The highest values were recorded for sample $1(0.880)$ and sample 4 (0.817). In other samples, sorting values amounted to 0.754 (sample 3 ) and 0.741 (sample 5), and the lowest value was recorded for sample 2 (0.702) (Table 4).

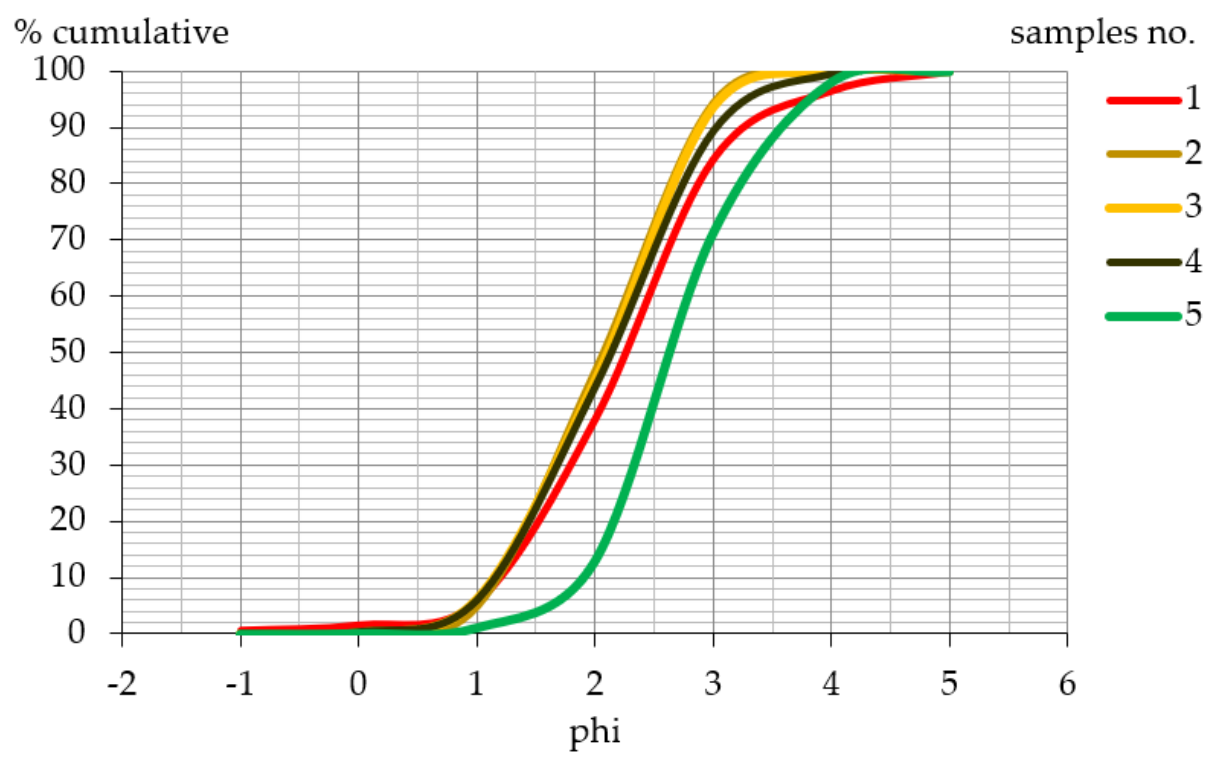

Figure 10. Grain-size distribution curves of mineral deposits from forms accumulated in beaver ponds. Numbers of samples $1-5$ are from Table 3.

Table 4. Sedimentological indicators (mean grain size and sorting) samples from Gajdówka valley.

\begin{tabular}{|c|c|c|c|c|c|}
\hline \multirow{2}{*}{$\begin{array}{c}\text { Sedimentological Indicators } \\
\text { (Folk and Ward (1922) } \\
\text { Method) }\end{array}$} & \multicolumn{5}{|c|}{ Samples Number } \\
\hline & 1 & 2 & 3 & 4 & 5 \\
\hline \multirow{2}{*}{ Mean grain size $(M z)$} & 2.187 & 2.038 & 2.055 & 2.094 & 2.721 \\
\hline & fine-grained sand & fine-grained sand & fine-grained sand & fine-grained sand & fine-grained sand \\
\hline \multirow{2}{*}{ Sorting $\left(\begin{array}{l}1 \\
1\end{array}\right)$} & 0.880 & 0.702 & 0.754 & 0.817 & 0.741 \\
\hline & moderately sorted & moderately sorted & moderately sorted & moderately sorted & moderately sorted \\
\hline
\end{tabular}


In addition, the average size of the grain determined according to sedimentological factors is identical in all cases. It is fine-grained sand (Table 4).

\subsection{Points at Which Sedimentary Material Is Supplied to the Stream and Deposited}

In forest ecosystems the supply of sedimentary material from watercourses to catchments is impeded. In a valley inhabited by beavers, at some points sediments are supplied to the watercourse from beaver burrows (Figure 11A) and erosion hollows (Figure 11B). Field observation shows that beavers live in burrows only. No beaver lodges were found in the study area. The slopes and flat bottom of the valley give plenty of evidence that beavers dig long stretches of burrows (Figure 12A) and migration tunnels. They used to do this in the past as a relict burrow was documented. A collapsed burrow shows a U-shaped profile and sticks with beaver teeth marks (Figure 12B). Another example is sediment deposition in front of the burrows. The entrance to the burrow is always located under the water. They can be seen only when the level of water in the pond drops. In front of the burrows, mineral sediments are often deposited and are later supplied to the watercourse.
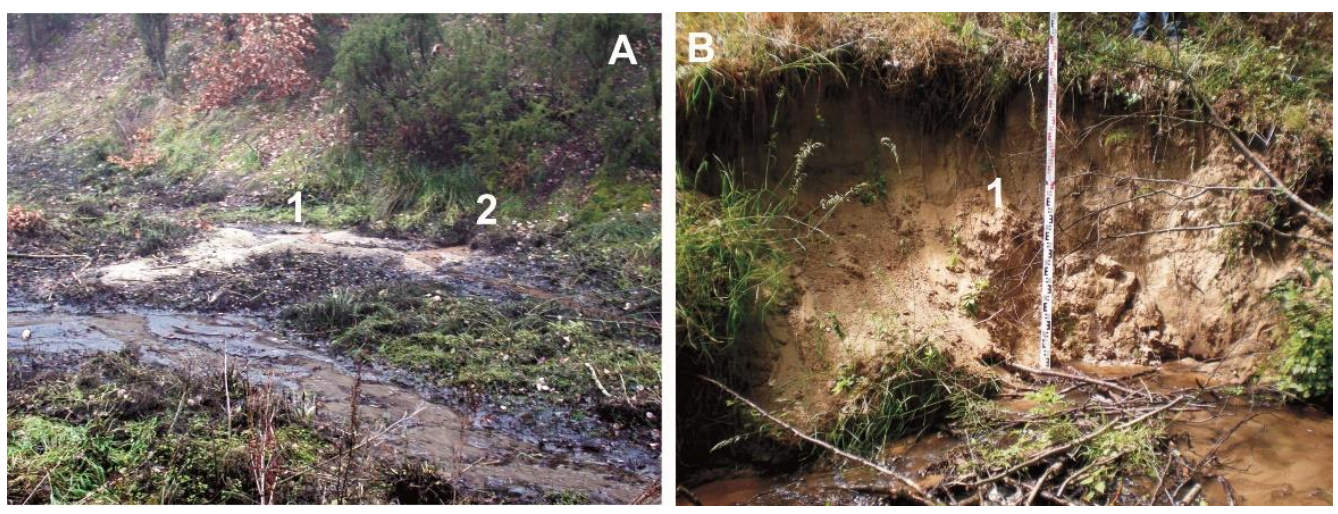

Figure 11. Examples of points of supply of mineral sediments to the watercourse induced by beavers in Gajdówka valley. Legend: part $(\mathbf{A})=1$-sands from beaver burrow, 2-entrance to beaver burrow; part $(\mathbf{B})=1$ - erosion hollow.
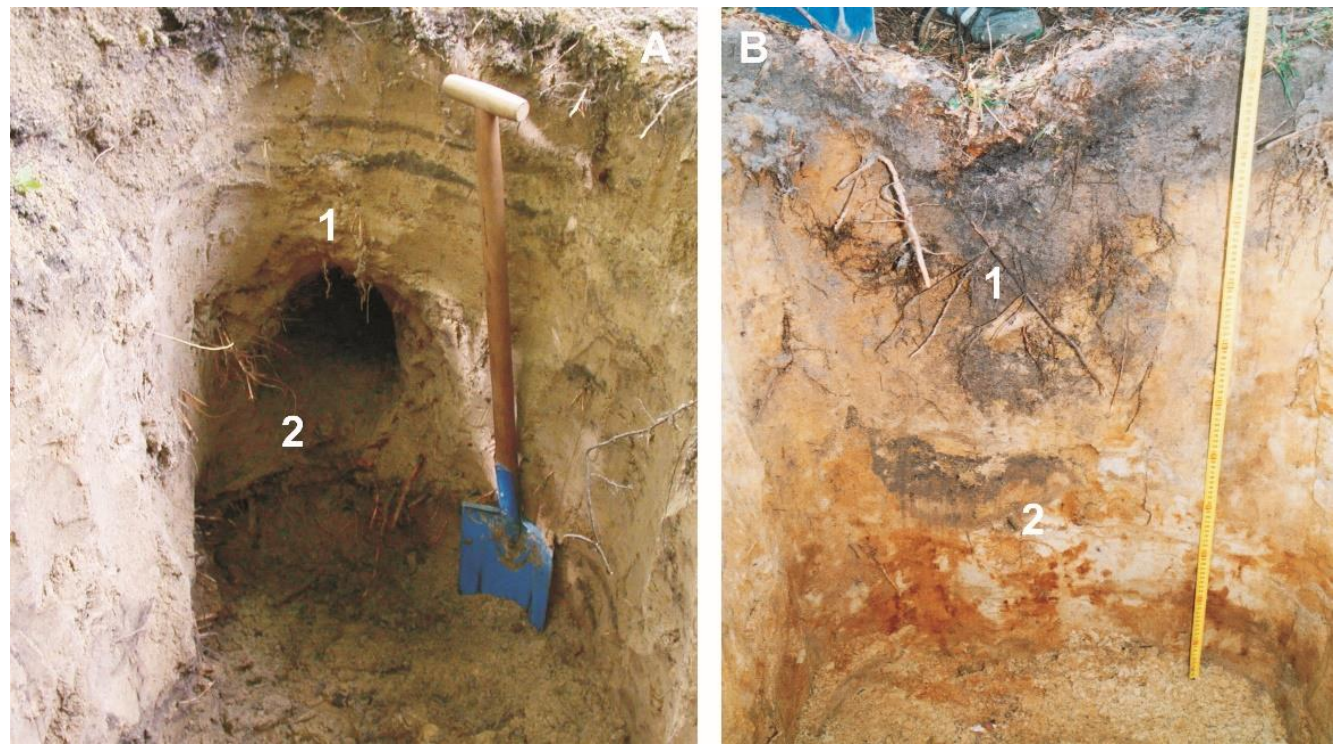

Figure 12. Examples of beaver burrows from the Gajdówka valley. Legend: part $(\mathbf{A})=1$-active beaver burrow, 2-sticks with beaver teeth marks; part $(\mathbf{B})=1$-fossil beaver burrow, 2-sticks with beaver teeth marks. 
Another source of sediment supply is erosion hollows. The hollows are mostly semioval and semicircular. Due to erosion, in pond 14 the slope retreated by about $4 \mathrm{~m}$. This is an isolated example; at other points, characteristic hollows cut into slopes at lengths up to $2 \mathrm{~m}$. These forms are a peculiar example recorded in the terrain relief after the beavers abandoned the valley. The forms will be analyzed in detail in the future since they are well exposed after the beavers abandoned their habitat.

In abandoned beaver ponds the layers of sediments grow horizontally and vertically. Field studies show that a moving alluvial fan can fill the beaver pond. A layer of sand with a thickness of $10 \mathrm{~cm}$ was deposited in almost the whole of pond 3 (Figure 13). In small ponds in the Gajdówka valley (ponds 8 and 9), the transported mineral sediments can fill the ponds up to the crest of the dam (Figure 14). In pond 8, mineral sediments raised the channel by $0.5 \mathrm{~m}$.
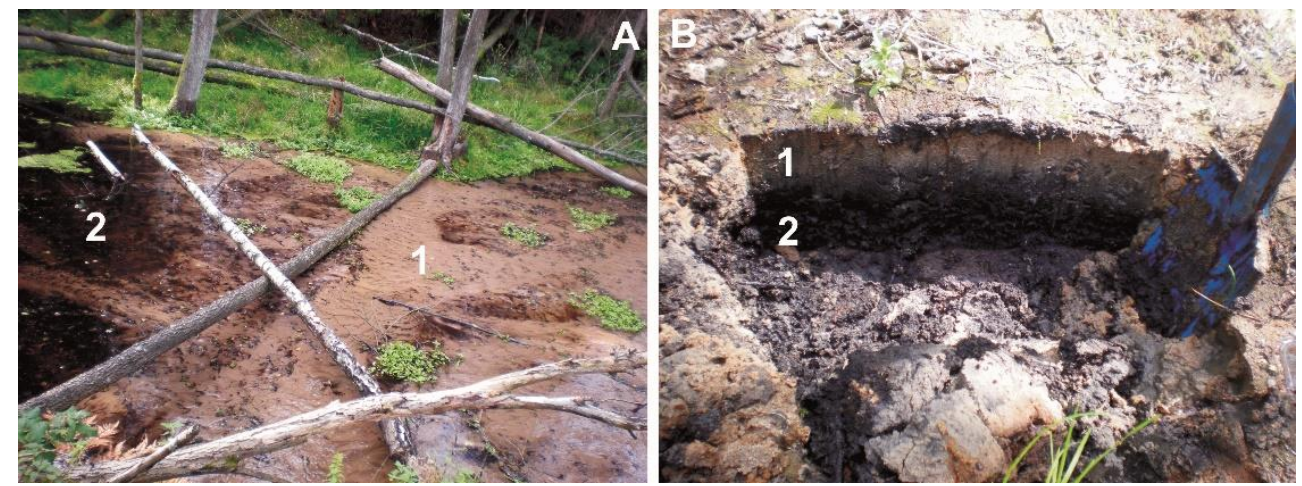

Figure 13. Increase in sediment in a beaver pond after beavers leave the habitat in Gajdówka valley (pond 3). Legend: part (A) and $(\mathbf{B})=1$-sands, 2-mineral-organic silt.
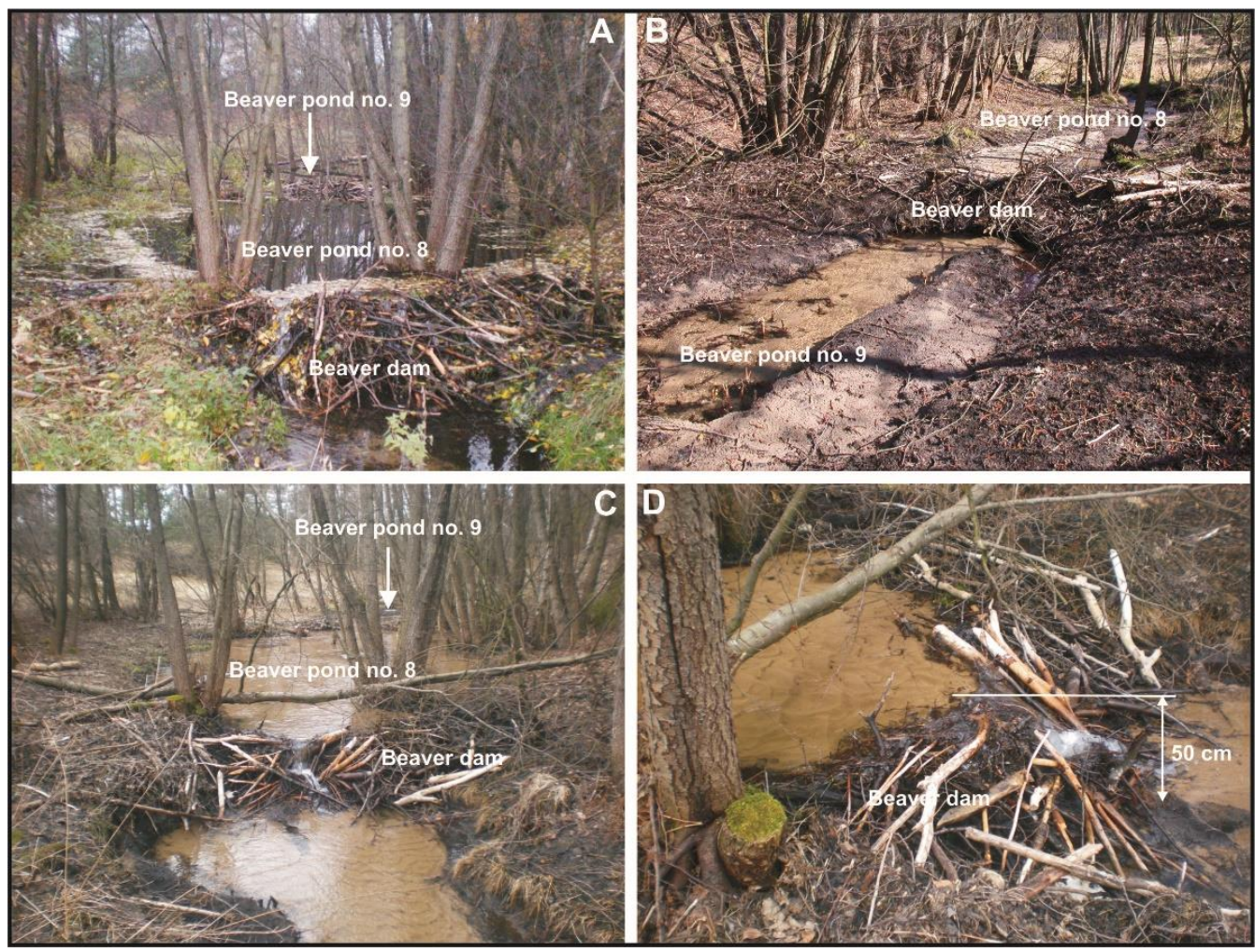

Figure 14. Filling of the ponds with mineral sediments in Gajdówka valley. Beaver pond 8 was filled with water up to the dam crest (A) in autumn 2008. In the spring of 2009, it was drained (B). In autumn 2009 (C), mineral sediments filled the pond, raising the level of the channel by $50 \mathrm{~cm}$ (D). 


\section{Discussion}

Beaver ponds can exist for up to several hundred years [13]. The construction of dams and, thus, the emergence of beaver ponds is closely linked to the presence of beavers in the river valley. They most often inhabit watercourses of the order I to IV. Researchers $[7,8,18,28]$ report various sizes of ponds. Beaver ponds with a large surface area (several hundred square meters) are excellent sites for the development of new ecosystems that are visited and inhabited by other species $[60,61]$. In the study area, floodplain ponds and channel ponds were identified. The floodplain ponds provide excellent living conditions for other species, improve the water regime in the valley and contribute to the improvement of biodiversity. Channel ponds are points at which mineral sediments are captured; after the habitat is abandoned, they quickly become degraded.

Sand is redeposited from the outwash plain of the Wda River and constitutes the main material building forms such as alluvial fans, levees, sand bars and microterraces. The presently formed levees and sand bars show clear structures giving evidence of the water flow energy and direction. The authors of [62] discovered small-scale diagonal stratification in the levees of the Warta River near Poznań. Diagonal tabular or wedge stratification of channel bars in braided rivers with sandy beds was reported in [63]. By contrast, massive sandy sediments occur in forms associated with beaver ponds. They appear in the course of a beaver pond formation (levees) or in an existing pond (channel bars). Perhaps their small size has an influence on the structure of sediments. In his monograph on vertical sedimentation in the Parseta River Valley after the spring swell of waters in 1979, the author of [63] noted that levees are sometimes small forms with unclear structure. Massive structures can also be due to factors such as plant succession, rainfall, animals and human activity. Levees analyzed in [64] were not very thick (ten to twenty centimeters) and did not clearly stand out from the relief of the valley. By contrast, levees in beaver ponds are clearly discernible forms with thickness exceeding several dozen centimeters.

Alterations in the flat bottom of the valley inhabited by beavers were described in [21]. The authors presented their detailed observations regarding alterations in the flat bottom of the river valley induced by beaver activity. These transformations were caused by alterations in the river channel pattern and increased deposition of sediments. Considering channel transfer due to beaver activity in the Gajdówka valley, it can be concluded that a first-order stream inhabited by beavers is transformed by the construction of dams and formation of ponds and is subject to erosion processes and deposition of mineral sediments. The deposition of sediments and disappearance of ponds leads to backfilling of the ponds, and thereby the level of the flat bottom of the valley is raised.

The authors of [7] note that in the past very large quantities of sediments had to be accumulated in beaver ponds. In the United States, before the European colonization, beavers would adapt the environment to their needs. They were not threatened by anyone, so the authors believe that millions of cubic meters of sediments could have been accumulated in beaver ponds in the United States. In the analyzed beaver ponds, the volume of sediments was established as $252 \mathrm{~m}^{3}$. This figure indicates that accumulation does occur and leads to the deposition of sediments in the valley. The result does not reflect the overall amount of accumulated sediments since it cannot be clearly established how much sediment is continuously redeposited from pond to pond.

Sediments deposited in beaver ponds can be affected by erosion after the dam is destroyed. Some authors present evidence of restoring the river incision to that observed before the formation of a beaver pond and of insignificant lateral erosion of the river channel [7]. Sediments that were not eroded remain in the pond and in the channel. This is where fine-grained sediments can potentially accumulate [65]. The occurrence of bedforms in beaver ponds in the analyzed Gajdówka River Valley was associated with the flow of water and a high volume of sediments transported by the stream building such bedforms. These are depositional forms (alluvial fans, levees and sandy shadow dunes) and erosive forms (microterraces). They are not permanently marked in the landscape of the valley as they are small and can be scoured or overgrown. 
Changes in the relief of river valleys in the past of the Yellowstone National Park were presented in [23]. Records of sediments deriving from beaver ponds, supported by C14 dating results, show that beavers lived in this area for a very long time (7000 years with intervals). Sediments in beaver ponds derive from local sources and here they are represented by gravel and sand. In the analyzed Gajdówka valley they are represented only by layers of sand of different thickness and mineral-organic silt. This implies that beaver pond sediments have been preserved even in mountain areas (Yellowstone National Park). In the Gajdówka valley, a relict beaver burrow was found but without some additional evidence (pieces of wood with beaver teeth marks) it is impossible to establish clearly which of them date back to the previous colonization of the valley. Beaver pond sediments found in Poland were described in several monographs and articles [51-54].

The authors of [27] indicated that fine-grained sediments are accumulated in beaver ponds. They reported that about $37 \mathrm{~m}^{3}$ of sediments were deposited in six beaver ponds. The amount of sedimentary material in ponds depends on the plant cover of the area intersected by the watercourse inhabited by beavers. In woodless areas the supply of mineral sediments is increased as a result of burrow digging and undercutting of the stream channel by erosion downstream of the dam. In the analyzed area, 17 active and inactive ponds were discovered which over 3 years accumulated about $250 \mathrm{~m}^{3}$ of finegrained sediments. In forest ecosystems the supply of sediments is impeded, and in the Gajdówka valley, beavers have played a large part in the supply.

\section{Conclusions}

The studies showed that the activity of beavers in the Gajdówka valley has a significant impact on the landscape. Sediments are deposited in beaver ponds and various forms are created by deposition and erosion. These forms are not always present in the ponds. Their origin is determined by the rate at which the beaver pond is filled, the amount of supplied mineral sediments and the surface area of and flow through the pond (single channel or multichannel). These forms are overgrown with vegetation and influenced by fluvial erosion processes, so after some time they are not visible in the valley. On the other hand, sediments that build them can be misinterpreted in geological and geomorphological analyses of small river valleys. Sediment thickness analysis points to a large percentage of mineral sediments (thickness of sediments). In forestland the supply of sediments to the watercourse is impeded or even impossible. Vegetation growing on the banks suppresses the supply of mineral sediments from the outside. Mineral sediments are supplied to the watercourse due to beaver activity only. It has a direct impact on the transformations of the flat beds of watercourses inhabited by beavers. The described forms are located in lowlands where the supply of sediments to watercourses is smaller, and in such cases, the impact of beavers should not be neglected in geomorphological and paleogeographic studies. Sandy areas are excellent burrow digging sites for beavers, and the burrows can be tens of meters long. In addition, the processes of erosion connected with the lateral flow of water through the dam lead to the development of erosion hollows of different sizes. This should be more thoroughly analyzed for the Polish Plain since many valleys formed by erosion have wide flat bottoms. In such cases the activity of beavers cannot be excluded. With time abandoned chambers and burrows collapse or are backfilled. Collapsed chambers and burrows create negative (concave) surface forms that-after the surface is filled/leveled-turn into relict forms. This will be the subject of our future studies.

Funding: This research and APC were funded by the Project Supporting Maintenance of the Research Potential of the Institute of Geography at the Kazimierz Wielki University (grant number $\mathrm{BS} / 2016 / \mathrm{N} 1$ ).

Institutional Review Board Statement: Not applicable.

Informed Consent Statement: Not applicable.

Data Availability Statement: The data presented in this study are available on the request to the corresponding author. 
Acknowledgments: I would like to thank the anonymous reviewers for their valuable comments. Besides, I would also like to thank my promoter Zbigniew Śnieszko for his scientific orientation.

Conflicts of Interest: The author declares no conflict of interest.

\section{References}

1. Nolet, B.; Rosell, F. Comeback of the beaver Castor fiber: An overview of old and new conservation problems. Biol. Conserv. 1998, 83, 165-173. [CrossRef]

2. Halley, D.J.; Rosell, F. The beaver's reconquest of Eurasia: Status, population development, and management of a conservation success. Mammal. Rev. 2002, 32, 153-178. [CrossRef]

3. Halley, D.J.; Rosell, F. Population and distribution of European beavers Castor fiber. Lutra 2003, 46, 91-102.

4. Halley, D.J.; Rosell, F.; Saveljev, A. Population and distribution of Eurasian beaver (Castor fiber). Balt. For. 2012, 18, 168-175.

5. Wróbel, M. Population of Eurasian beaver (Castor fiber) in Europe. Short Communication. Glob. Ecol. Conserv. 2020, 23, e01046. [CrossRef]

6. Halley, D.J.; Saveljev, A.P.; Rosell, F. Population and distribution of beavers Castor fiber and Castor canadensis in Eurasia. Mammal Rev. 2021, 51, 1-24. [CrossRef]

7. Butler, D.R.; Malanson, G.P. The geomorphic influences of beaver dams and failures of beaver dams. Geomorphology 2005, 71, 48-60. [CrossRef]

8. Gurnell, A.M. The hydrogeomorphological effects of beaver dam-building activity. Prog. Phys. Geogr. 1998, 22, 167-189. [CrossRef]

9. Laland, K.N.; Boogert, N.J. Niche construction, co-evolution and biodiversity. Ecol. Econ. 2010, 69, 731-736. [CrossRef]

10. Westbrook, C.J.; Cooper, D.J.; Butler, D.R. Beaver hydrology and geomorphology. In Treatise on Geomorphology; Shroder, J.F., Ed.; Elsevier: Amsterdam, The Netherlands, 2013; pp. 293-306.

11. Westbrook, C.J.; Ronnquist, A.; Bedard-Haughn, A. Hydrological functioning of a beaver dam sequence and regional dam persistence during an extreme rainstorm. Hydrol. Process. 2020, 34, 3726-3737. [CrossRef]

12. Arismendi, I.; Penaluna, B.E.; Jara, C.G. Introduced beaver improve growth of non-native trout in Tierra del Fuego. S. Am. Ecol. Evol. 2020, 10, 9454-9465. [CrossRef] [PubMed]

13. Czech, A. Bóbr. Monografie Przyrodnicze; Wyd. Lubelskiego Klubu Przyrodników: Świebodzin, Poland, 2000; pp. 1-99. ISBN 8387846-15-5.

14. Naiman, R.J.; Johnston, C.A.; Kelley, J.C. Alteration of north American Streams by beaver. BioScience 1988, 38, 753-762. [CrossRef]

15. Chaubey, I.; Ward, G.M. Hydrologic budget analysis of a small natural wetland in Southeast USA. J. Environ. Inform. 2006, 8 , 10-21. [CrossRef]

16. Puttock, A.; Graham, H.A.; Cunliffe, A.M.; Elliott, M.; Brazier, R.E. Eurasian beaver activity increases water storage, attenuates flow and mitigates diffuse pollution from intensively-managed grasslands. Sci. Total Environ. 2017, 576, 430-443. [CrossRef] [PubMed]

17. Westbrook, C.J.; Cooper, D.J.; Baker, B.W. Beaver dams and overbank floods influence groundwater-surface water interactions of a Rocky Mountain riparian area. Water Resour. Res. 2006, 42, W06404. [CrossRef]

18. Butler, D.R.; Malanson, G.P. Sedimentation rates and patterns in beaver ponds in a mountain environment. Geomorphology 1995, 13, 255-269. [CrossRef]

19. Meentemeyer, R.K.; Butler, D.R. Hydrogeomorphic effects of beaver dams in Glacier National Park, Montana. Phys. Geogr. 1999, 20, 436-446. [CrossRef]

20. De Visscher, M.; Nyssen, J.; Pontzeele, J.; Billi, P.; Frankl, A. Spatio-temporal sedimentation patterns in beaver ponds along the Chevral river, Ardennes, Belgium. Hydrol. Process 2014, 28, 1602-1615. [CrossRef]

21. John, S.; Klein, A. Hydrogeomorphic effects of beaver dams on floodplain morphology: Avulsion processes and sediment fluxes in upland valley floors (Spessart, Germany). Quaternaire 2004, 15, 219-231. [CrossRef]

22. Persico, L.; Meyer, G. Holocene beaver damming, fluvial geomorphology, and climate in Yellowstone National Park, Wyoming. Quat. Res. 2009, 71, 340-353. [CrossRef]

23. Persico, L.; Meyer, G. Natural and historical variability in fluvial processes, beaver activity, and climate in the Greater Yellowstone Ecosystem. Earth Surf. Process. Landf. 2013, 38, 728-750. [CrossRef]

24. Pollock, M.M.; Beechie, T.J.; Jordan, C.E. Geomorphic changes upstream of beaver dams in Bridge Creek, an incised stream channel in the interior Columbia River basin, eastern Oregon. Earth Surf. Process. Landf. 2007, 32, 1174-1185. [CrossRef]

25. Polvi, L.E.; Wohl, E. The beaver meadow complex revisited-the role of beavers in post-glacial floodplain development. Earth Surf. Process. Landf. 2012, 37, 332-346. [CrossRef]

26. Levine, R.; Meyer, G.A. Beaver dams and channel sediment dynamics on Odell Creek, Centennial Valley, Montana, USA. Geomorphology 2014, 205, 51-64. [CrossRef]

27. Levine, R.; Meyer, G.A. Beaver-generated disturbance extends beyond active dam sites to enhance stream morphodynamics and riparian plant recruitment. Sci. Rep. 2019, 9, 8124. [CrossRef]

28. Johnston, C.A.; Naiman, R.J. Aquatic patch creation in relation to beaver population trends. Ecology 1990, 71, 1617-1621. [CrossRef]

29. Johnston, C.A. Wetland soil and landscape alteration by beavers. In Wetland Soils. Genesis, Hydrology, Landscapes and Classification; Richardson, J.L., Vepraskas, M.J., Eds.; CRC Press LLC: Boca Raton, FL, USA, 2001; pp. 391-408. 
30. Naiman, R.J.; Melillo, J.M.; Hobbie, J.E. Ecosystem alteation of boreal forest streams by beaver (Castor canadensis). Ecology 1986, 67, 1254-1269. [CrossRef]

31. Nummi, P. Simulated effects of the beaver on vegetation, invertebrates and ducks. Ann. Zool. Fenn. 1989, 26, 43-52.

32. Ruedemann, R.; Schoonmaker, W.J. Beaver-dams as geologic agents. Science 1938, 88, 523-525. [CrossRef]

33. Ives, R.L. The beaver-meadow complex. J. Geomorphol. 1942, 5, 191-203.

34. Garrison, G.C. Pollen stratigraphy and age of an early postglacial beaver site near Columbus, Ohio. Ohio J. Sci. 1967, 7, 96-105.

35. Robinson, S.; Beaudoin, A.B.; Froese, D.G.; Doubt, J.; Clague, J.J. Plant Macrofossils Associated with an Early Holocene Beaver Dam in Interior Alaska. Arctic 2007, 60, 430-438. [CrossRef]

36. Wells, C.E.; Hodgkinson, D.; Huckerby, E. Evidence for the possible role of beaver (Castor fiber) in the prehistoric ontogenesis of a mire in north-west England, UK. Holocene 2000, 10, 503-508. [CrossRef]

37. Aalto, M.J.; Hirvas, H.; Niemelä, J. An interglacial beaver dam deposit at Vimpeli, Ostrobothnia, Finland. Geol. Surv. Finland 1989, $348,1-34$.

38. Soja, R. Środowiskowe skutki reintrodukcji bobra (Castor fiber) w doliny rzek Karpackich. In Przewodnik Konferencji "Funkcjonowanie Geosystemów Dolinnych w Warunkach Zmian Klimatu i Narastania Antropopresji Późnego Glacjatu i Holocenu"; Wydział Nauk o Ziemi Uniwersytetu Śląskiego: Sosnowiec, Poland, 1996; pp. 45-46.

39. Witt, A. Wpływ stawów bobrowych na rozwinięcie małych koryt rzecznych w Wielkopolsce północnej. Dorobek i pozycja polskiej geomorfologii u progu XXI wieku. In V Zjazd Geomorfologów Polskich; Streszczenia Referatów; Wydawnictwo UMK: Torun, Poland, 2000; pp. 142-143.

40. Kobojek, E. Środowiskowe skutki reintrodukcji bobra (Castor fiber) w dolinie Rawki. Przeglad Geogr. 2005, 77, 383-396.

41. Kobojek, E. Wpływ działalności bobrów na lokalne procesy fluwialne w wybranych rzekach równiny łowicko-błońskiej. Acta Univ. Lodz. Folia Geogr. Phys. 2013, 12, 17-22. [CrossRef]

42. Szpikowska, G.; Szpikowski, J. Właściwości fizykochemiczne wód rozlewisk bobrowych w dolinie Kłudy (górna Parsęta). Monit. Sr. Przyr. 2012, 3, 95-102.

43. Szpikowski, J.; Szpikowska, G. Akumulacja osadów w rozlewiskach bobrowych w 'świetle oceny wielkości denudacji mechanicznej zlewni młodoglacjalnej (Kłuda, Pomorze Zachodnie). In Geneza, Litologia i Stratygrafia Utworów Czwartorzędowych; Kostrzewski, A., Stach, A., Majewski, M., Eds.; Wydawnictwo UAM w Poznaniu: Poznań, Poland, 2018; Volume 7, pp. 197-204. ISBN 978-83-936793-0-0.

44. Rurek, M. Lokalne zmiany środowiska przyrodniczego wywołane działalnością bobra europejskiego (Castor fiber L.) w okolicy Trzebcin (powiat tucholski). J. Health Sci. 2013, 3, 247-256.

45. Stopka, R. Geomorfologiczne skutki działalności bobra europejskiego Castor fiber w dolinie górnego Sanu. Rocz. Bieszcz. 2011, 19, 319-334.

46. Giriat, D.; Gorczyca, E.; Sobucki, M. Beaver ponds' impact on fluvial processes (Beskid Niski Mts., SE Poland). Sci. Total Environ. 2016, 544, 339-353. [CrossRef]

47. Gorczyca, E.; Krzemień, K.; Sobucki, M.; Jarzyna, K. Can beaver impact promote river renaturalization? The example of the Raba River, southern Poland. Sci. Total Environ. 2018, 615, 1048-1060. [CrossRef] [PubMed]

48. Grygoruk, M. Metodyka szacowania objętości retencyjnej stawów bobrowych oraz ich oddziaływania na stosunki wodne zlewni leśnych. Studia I Mater. Cent. Edukac. Przyr. -Leśnej 2008, 2, 162-172.

49. Grygoruk, M.; Nowak, M. Spatial and temporal variability of channel retention in a lowland temperate forest stream settled by European beaver (Castor fiber). Forests 2014, 5, 2276-2288. [CrossRef]

50. Fajer, M.; Malik, I.; Waga, J.M.; Wistuba, M.; Woskowicz-Ślęzak, B. Współczesne wykorzystanie przez bobra europejskiego Castor fiber antropogenicznie przekształconych dolin rzecznych (przykłady z Równiny Opolskiej i Wyżyny Woźnicko-Wieluńskiej). Prz Geogr. 2017, 89, 467-489. [CrossRef]

51. Rurek, M.; Śnieszko, Z.; Makohonienko, M. Contemporary and Fossil Beaver Ponds in Small River Valleys on the Area of Bory Tucholskie (North European Plain); Kazimierz Wielki University Press: Bydgoszcz, Poland, 2016; pp. 1-136. ISBN 978-83-8018-109-0. (In Polish with English Summary)

52. Śnieszko, Z.; Rurek, M.; Rzętała, M. Significance of relief-forming activities by Castor fiber L. for the evolution of Holocene floodplains of small river valleys (results of studies conducted in Poland). In Proceedings of the 17th International Multidisciplinary Scientific GeoConference (SGEM 2017), Albena, Bulgaria, 29 June-5 July 2017; Volume 17, pp. 523-529.

53. Śnieszko, Z.; Rurek, M.; Hojan, M. The Role of Beavers in the Holocene Landscape Evolution of the Small River Valleys (the Tuchola Forest-North European Plain); Kazimierz Wielki Univeristy Press: Bydgoszcz, Poland, 2020; pp. 1-109. ISBN 978-83-8018-344-5.

54. Śnieszko, Z.; Rurek, M.; Hojan, M. Medieval Relict Beaver Ponds in the Polish Plain: Studies from the Tuchola Forest. Water 2021, 13, 777. [CrossRef]

55. Ministerstwo Środowiska. Szczegótowa Mapa Geologiczna Polski 1:50 000, Arkusz: Cekcyn No. 204; Ministerstwo Środowiska: Warszawa, Poland, 2009.

56. Główny Urząd Geodezji i Kartografii. Mapa Topograficzna 1:25000, Arkusz: 334.44; Główny Urząd Geodezji i Kartografii: Warszawa, Poland, 1974.

57. Geoportal. Available online: https:/ /www.geoportal.gov.pl/ (accessed on 5 October 2021).

58. Wentworth, C.K. A Scale of Grade and Class Terms for Clastic Sediments. J. Geol. 1922, 30, 377-392. [CrossRef] 
59. Folk, R.L.; Ward, W.C. Brazos River bar: A study in the significance of grain size parameters. J. Sediment. Res. 1957, 27, 3-26. [CrossRef]

60. Dalbeck, L.; Lüscher, B.; Ohlhoff, D. Beaver ponds as habitat of amphibian communities in a central European highland. Amphibia-Reptilia 2007, 28, 493-501. [CrossRef]

61. Dalbeck, L.; Weinberg, K. Artificial ponds: A substitute for natural Beaver ponds in a Central European Highland (Eifel, Germany)? Hydrobiologia 2009, 630, 49-62. [CrossRef]

62. Skolasińska, K.; Rotnicka, J. Pozakorytowe osady Warty zdeponowane w czasie powodzi zimowej 2010/2011 na zakolu rzeki w Marlewie (Poznań S). In Varia, Prace z Zakresu Geografii i Geologii; Biernacka, J., Kijowska, J., Eds.; Bogucki Wydawnictwo Naukowe: Poznań, Poland, 2011; pp. 7-25.

63. Zieliński, T. Cykliczność w osadach rzek roztokowych. Geologia 1998, 14, 68-119.

64. Zwoliński, Z. Sedymentacja osadów przyrostu pionowego na terasie zalewowej Parsęty. Bad. Fizjograf. Nad Pol. Zach. 1985, 35, 205-238.

65. Larsen, A.; Larsen, J.R.; Lane, S.N. Dam builders and their works: Beaver influences on the structure and function of river corridor hydrology, geomorphology, biogeochemistry and ecosystems. Earth-Sci. Rev. 2021, 2018, 103623. [CrossRef] 